UDK 366.542:347.44

https://doi.org/10.18485/union_pf_ccr.2021.ch13

Doc. dr Slobodan Vukadinović*

\title{
MEHANIZMI KOLEKTIVNE ZAŠTITE POTROŠAČA OD NEPRAVIČNIH UGOVORNIH ODREDABA
}

\begin{abstract}
Apstrakt: Predmet razmatranja je uloga i način postupanja različitih organa u cilju zaštite kolektivnih interesa potrošača, naročito od nepoštenih ugovornih odredaba. Ispituje se aktuelno stanje u Srbiji i stvarni domašaj postojećih mehanizama, njihova delotvornost i rezultati, a posebno: upravna kontrola, odnosno postupak koji sprovodi nadležno ministarstvo, ovlašćenja Narodne banke Srbije, uloga Suda časti i mere koje može izreći, domašaj uloge udruženja potrošača, značaj potrošačkog obrazovanja. Autor istražuje uporednopravna rešenja, pri čemu posebnu pažnju posvećuje potrošačkom ombudsmanu $i$ drugim specijalizovanim ombudsmanima. Na primeru Australije autor analizira sistem sektorskih industrijskih ombudsmana i poverenika, te uz konkretne rezultate efikasnosti ovih tela pokazuje njihovu delotvornost u zaštiti potrošača. Na osnovu istraženih primera dobre prakse u stranim pravima i komparativnih iskustava, dati su predlozi za dalje unapređenje postojeće kombinacije mehanizama zaštite kolektivnih interesa potrošača u Srbiji i zaštite potrošača u celini.
\end{abstract}

Ključne reči: potrošači, kolektivna zaštita, kolektivni interes, nepravične ugovorne odredbe, upravna kontrola, ombudsman, sud časti, Narodna banka.

\section{UVOD}

Nacionalni propisi država u uporednom pravu po pravilu ne sadrže eksplicitnu definiciju kolektivnog interesa potrošača, barem retko sadrže pozitivnu definiciju. Iz francuskog prava potiče, ${ }^{1}$ a dalje je implementirana u direktive EU, negativna definicija kolektivnih interesa potrošača kao interesa koji ne predstavljaju zbir interesa pojedinaca povređenih (oštećenih) povredom prava. ${ }^{2} \mathrm{Naš}$ važeći Zakon o zaštiti potrošača (dalje: ZZP) određuje da povreda kolektivnog interesa potrošača postoji: (1) kada se ukupnom broju od najmanje deset po-

* Docent Pravnog fakulteta Univerziteta Union u Beogradu i spoljni saradnik Instituta za uporedno pravo u Beogradu; e-mail: slobodan.vukadinovic@pravnifakultet.rs, https://orcid. org/0000-0002-4692-321X.

Rad je napisan kao rezultat istraživanja na naučnom projektu Pravnog fakulteta Univerziteta Union u Beogradu - Zaštita kolektivnih interesa potrošača u srpskom i uporednom pravu.

1 Babović, B., 2014, Zaštita kolektivnih interesa potrošača, Anali Pravnog fakulteta u Beogradu, 2, str. 217-218, sa pozivanjem na stav 2. preambule Direktive 98/27/EZ.

2 Konsolidovana verzija Direktive 2009/22/EZ, stav 3. preambule. 
trošača, istovetnom radnjom, odnosno na istovetan način, od strane istog lica, povređuje pravo koje im je zagarantovano ovim zakonom ili (2) u slučaju nepoštene poslovne prakse u smislu čl. 17-23. ovog zakona, odnosno nepravičnih odredaba u potrošačkim ugovorima u smislu čl. 41. do 45. ovog zakona. ${ }^{3}$ U stavu 2. člana 145. određuje se da povreda kolektivnog interesa potrošača iz stava 1. tačka 1) ovog člana postoji i u slučajevima kada se povređuju prava ukupnom broju potrošača koji je manji od broja deset, ako nadležni organ utvrdi da je došlo do povrede kolektivnog interesa potrošača uzimajući u obzir naročito trajanje i učestalost postupanja trgovca, kao i činjenicu da li takvo postupanje ispoljava negativne efekte prema svakom potrošaču u datoj činjeničnoj situaciji. Ovde treba reći i da Direktiva 93/13/EEZ, koja je primenjena u našem ZZP-u, nalaže državama članicama da obezbede primerena i efikasna sredstva kako bi se onemogućilo kontinuirano korišćenje nepravičnih odredaba u potrošačkim ugovorima. ${ }^{4}$

Ono što je novina na nivou EU a odnosi se na nepoštene ugovorne odredbe jesu Smernice za tumačenje i primenu Direktive 93/13/EC o nepoštenim odredbama u potrošačkim ugovorima, donete 2019. godine. ${ }^{5}$ Smernice su veoma korisne jer sadrže na strukturiran način tumačenja koja je Sud pravde Evropske unije dao o ključnim pojmovima i odredbama Direktive o nepoštenim odredbama u potrošačkim ugovorima. Smernicama su uzete u obzir presude Suda objavljene do 31 . maja 2019. godine. $^{6}$

U pogledu očekivanih tokova u pravu EU, od značaja je i vest iz juna 2020. godine da su pregovarači na nivou EU postigli politički dogovor o predlogu direktive o kolektivnim tužbama za zaštitu kolektivnih interesa potrošača. ${ }^{7}$

Prosečan potrošač nema ni vremena ni znanja da prilikom zaključenja brojnih tipiziranih ugovora pročita i razume značenje svake odredbe i prepozna mo-

3 Član 145. Zakona o zaštiti potrošača (Sl. glasnik RS, br. 62/14, 6/16 - dr. zakon i 44/18 - dr. zakon).

4 Član 7. stav 1. Direktive 93/13/EEZ.

5 Guidance on the interpretation and application of Council Directive 93/13/EEC on unfair terms in consumer contracts, 2019/C 323/04, Official Journal of the European Union, 27. 9. 2019.

6 Pored navedenog, 27. 11. 2019. godine doneta je Direktiva 2019/2161 o izmeni Direktive 93/13/EEZ, direktiva 98/6/EZ, 2005/29/EZ i 2011/83/EU u pogledu boljeg izvršavanja i modernizacije pravila EU o zaštiti potrošača.

7 Predlog ove direktive (Proposal for a Directive of the European Parliament and of the Council on representative actions for the protection of the collective interests of consumers, and repealing Directive 2009/22/EC), dostupan je na: https:/eur-lex.europa.eu/legal-content/ EN/TXT/?uri=CELEX:52018PC0184. Prema dogovorenom kompromisu, svaka država članica moraće da odabere najmanje jedno telo, poput organizacije za zaštitu potrošača, koje posluje neprofitno i ispunjava stroge kriterijume, a nadzire ga javno telo. To telo će moći da pokrene kolektivnu tužbu u ime grupe potrošača. Kako bi se izbegla opasnost od zloupotreba, zlonamerno ili neutemeljeno parničenje, predviđeno je da strana koja izgubi spor snosi troškove postupka. Detaljnije: https://www.instore.rs/svet/eu-postigla-dogovor-o-kolektivnoj-zastiti-potrosaca-12070.html (vest objavljena 24. 6. 2020). Videti i saopštenje za javnost Evropskog parlamenta od 22. 6. 2020. pod nazivom: New rules allow EU consumers to defend their rights collectively, dostupno na: https://www.europarl.europa.eu/news/en/pressroom/20200619IPR81613/new-rules-allow-eu-consumers-to-defend-their-rights-collectively. 
guće rizike koji ga mogu dovesti u neravnopravan, nepovoljan, nepravičan i nefer položaj, a nekada ih možda i razume, ali nema drugi način da zadovolji svoju opravdanu potrebu ili legitiman interes, te je faktički primoran da ih prihvati da bi zadovoljio elementarne potrebe. Zbog toga je neophodna ne samo reaktivna, tj. postventivna zaštita kada do takve situacije dođe već, imajući u vidu da je reč o odredbama u ugovorima koji se toliko rasprostranjeno koriste da su od značaja za sve potrošače i društvo u celini kao kolektivitet, neophodna je kolektivna preventivna zaštita interesa potrošača, kako bi potrošači unapred bili adekvatno zaštićeni od takvih ponovljenih situacija i kako bi se predupredila situacija da više lica pokreće postupke ili sporove povodom iste ili istovrsne ugovorne odredbe.

Polazeći od činjenice da se nepoštene ugovorne odredbe neretko nalaze u raznim tipskim ugovorima i opštim uslovima koji se danas svakodnevno i masovno koriste, moglo bi se s razlogom reći da kod navedenih odredaba i takvih ugovora javni interes dolazi do mnogo većeg izražaja nego kod pojedinačnog ugovora. ${ }^{8} \mathrm{U}$ tom smislu bi se onda moglo reći da postoji veća potreba za nadzorom nad ovakvim ugovorima, odnosno njihovom kontrolom, ${ }^{9}$ kako bi se onemogućile zloupotrebe i pravovremeno preduzele mere da se spreče štetne posledice. Navedena kontrola bi se mogla klasifikovati prema različitim kriterijumima: (1) prema grani vlasti koja ustanovljava ili vrši kontrolu: zakonodavna, administrativna i sudska; (2) prema podeli prava na javno i privatno: javnopravna i privatnopravna; (3) prema sadržini kontrole, predmetu, tj. težištu kontrolnog mehanizma: kontrola punovažnosti, tj. zaključenja, kontrola sadržine i kontrola tumačenja; ${ }^{10}$ (4) prema subjektu koji vrši kontrolu i postupku koji se sprovodi: upravna i sudska; (5) prema vremenskom kriterijumu (kada se sprovodi): prethodna i naknadna, odnosno, kako se ponegde drugačije navodi: preventivna (ex ante) i reaktivna (ex post). ${ }^{11}$ Ako se pođe od subjekata koji sprovode kontrolu, onda bi se pored države, koja to čini kako kroz zakonodavnu, izvršnu i sud-

8 Videti: Babić, I., 2011, Građansko pravo: uvod u građansko pravo, Beograd, Novi Sad, JP Službeni glasnik i Fakultet za evropske pravno-političke studije Univerziteta Singidunum, str. 64.

9 U pogledu neophodnosti i potrebe za kontrolom, još naša starija pravna teorija je ukazala i na zahtev društvenog morala da ne dopusti iskorišćavanje predominantnog ekonomskog položaja na štetu drugih pojedinaca, pa čak i celog društva. O tome: Blagojević, B., 1934, Ugovori po pristanku - formularni ugovori (doktorska rasprava), Beograd, Pravni fakultet Univerziteta u Beogradu, str. 87-89.

10 Kada je u pitanju kontrola prema težištu kontrolnog mehanizma, pravna teorija ukazuje da iako kontrolni mehanizmi opštih uslova nisu istovetni u pravnim sistemima, usled činjenice da težište u jednoj zemlji može biti na zaključenju (kako je tradicionalno u Italiji i Velikoj Britaniji), u drugoj na tumačenju (kako je tradicionalno u Grčkoj, Portugaliji i Brazilu), a u trećoj na sadržini (kako je tradicionalno u Nemačkoj i SAD), olakšano zaključenje se može kompenzovati putem stroge kontrole sadržine i obrnuto: strogi propisi u pogledu zaključenja ugovora putem opštih uslova poslovanja mogu voditi ka tome da kontrola sadržine postane potpuno izlišna. Ukazuje se i da postoje zemlje kod kojih sva tri kontrolna mehanizma imaju isti značaj (npr. Holandija), kao i one u kojima opšti uslovi podležu apstraktnoj prethodnoj kontroli putem upravnog odobrenja ili provere od strane tzv. ombudsmana (npr. Norveška, Švedska). Videti detaljnije: Đurđević, N., 1994, Kontrola opštih uslova poslovanja po osnovu pravičnosti, Pravni život, 11-12, str. 1544.

11 Detaljnije o navedenim vrstama kontrole opštih uslova poslovanja: Vukadinović, S., 2019, Opšti uslovi poslovanja u obligacionom i medunarodnom trgovinskom pravu: pojam, zaključe- 
sku vlast i kontrolu od strane specijalnih nezavisnih i „polunezavisnih“ državnih organa, moglo govoriti i o kontroli od strane udruženja građana, autonomnoj kontroli, odnosno kontroli javnog mnjenja, pa bi se u tom smislu kontrola mogla podeliti i na državnu i nedržavnu.

Kada govorimo o kontroli opštih uslova sa aspekta zaštite potrošača, a imajući u vidu podelu prava na javno i privatno, ${ }^{12}$ tradicionalno se svi instrumenti i postupci, koji zajedno čine sistem zaštite potrošača, dele na: (1) javnopravne, u koje se ubraja zaštita potrošača u upravnom postupku i sudska zaštita pred prekršajnim, krivičnim i upravnim sudovima i (2) privatnopravne, u koje se ubrajaju sudska zaštita u parničnom postupku, uključujući tu i parnični postupak za zaštitu kolektivnih potrošačkih interesa, kao i različiti oblici vansudskog rešavanja potrošačkih sporova. ${ }^{13}$ Podržavajući stanovište koje su u svojim radovima iznosili G. Betlem i S. Taboroši da danas više ne možemo govoriti o čistoti podele na javnopravni i privatnopravni model zaštite potrošača zbog složenosti pitanja uloge države $\mathrm{u}$ ispravljanju nedostataka tržišta, prof. dr Tatjana Jovanić u svom istraživanju ukazuje da je čak i jasna linija između upravnopravne i sudske zaštite potrošača dovedena u pitanje akcesornom ulogom uprave u zaštiti kolektivnih interesa potrošača. ${ }^{14}$ Jasno je da se ukazivanje prof. Jovanić odnosi na tadašnje stanje važećih propisa, imajući u vidu da je Ustavni sud na sednici održanoj 23. 5. 2013. godine utvrdio da odredbe čl. 494-505. Zakona o parničnom postupku, kojima je bila uređena zaštita kolektivnih prava i interesa građana kao poseban postupak, nisu u saglasnosti sa Ustavom i potvrđenim međunarodnim ugovorima. ${ }^{15}$

Uporednopravna iskustva pokazuju da su moguće i različite kombinacije vrsta, odnosno oblika kontrole i one se najčešće tako i dopunjuju, u svakoj državi različito u zavisnosti od specifičnog načina i perioda kada su uvođeni mehanizmi zaštite potrošača, tela i organi i kako su se njihova ovlašćenja menjala. U aktuelnim prilikama u Srbiji težište je na upravnoj kontroli ${ }^{16}$ te će u nastavku ona biti polazna tačka, nakon čega će biti razmotreni i drugi mehanizmi i sredstva koja doprinose kolektivnoj zaštiti potrošača od nepravičnih ugovornih odredaba.

nje, tipične klauzule i kontrola (doktorska disertacija), Pravni fakultet Univerziteta Union u Beogradu, str. 308.

12 O podeli prava na javno i privatno, iscrpno, sa naknadnom rečju unapred (povratak podele prava na javno i privatno): Vodinelić, V., 2016, Javno i privatno pravo, Beograd, Službeni glasnik.

13 Jovanić, T., Uloga uprave u zaštiti kolektivnih interesa potrošača, u: Bourgoignie, T., Jovanić, T. (eds.), 2013, Strengthening Consumer Protection in Serbia - Liber Amicorum Svetislav Taboroši, Beograd, Pravni fakultet Univerziteta u Beogradu, str. 312.

14 Ibid.

15 Odluka Ustavnog suda od 23. 5. 2013. u predmetu IUz-51/2012, Sl. glasnik RS, br. 49/13.

16 O razlozima zbog kojih se naš zakonodavac opredelio da sprovođenje postupka zaštite kolektivnih interesa potrošača poveri organima uprave a ne sudovima i o poređenju pravila ovog postupka s Preporukom Evropske komisije o zajedničkim načelima o kolektivnim zahtevima za propuštanje i kolektivnim zahtevima za naknadu štete u vezi s povredama prava koja su garantovana pravom Evropske unije (2013/396/EU) videti: Karanikić Mirić, M., 2014, Kolektivna zaštita potrošača u srpskom pravu, Anali Pravnog fakulteta Univerziteta u Zenici, 14, str. 57-83. 


\section{UPRAVNA KONTROLA I ZAŠTITA}

Upravna kontrola može postojati u raznim oblicima i varijantama, kao prethodna, tj. preventivna ili naknadna, tj. posteriorna. $U$ smislu kontrole ugovornih odredaba, vrstu upravne kontrole predstavljaju i situacije u kojima je potrebna saglasnost, tj. dozvola ili odobrenje, nadležnog organa uprave na opšte uslove poslovanja koji potencijalno sadrže sporne (nepoštene) ugovorne odredbe. U našoj starijoj doktrini naglašavalo se da je udeo administrativne vlasti u intervenciji kod ugovora po pristanku, tj. u zaštiti ekonomski slabijeg ugovarača, manji od udela zakonodavne i sudske vlasti, te da se administrativna vlast u ovo pitanje nije ni mešala sve do polovine XIX veka, ${ }^{17}$ kada se rad administrativne vlasti prevashodno sastojao u preventivnoj kontroli, sa tendencijom proširenja delokruga, koji se potom ogledao u intervenisanju u domenu stvaranja monopola, davanja koncesija i vršenja kontrole sadržine ugovora po pristanku. $U$ aktuelnim prilikama u Srbiji upravna kontrola je glavni vid zaštite kolektivnih interesa potrošača.

Svojevremeno je Zakon o trgovini iz 1993. godine sadržao izričitu odredbu po kojoj Savezno ministarstvo za poslove trgovine utvrđuje da li formularni ugovori sadrže klauzule kojima se narušava ravnopravnost saugovarača. ${ }^{18}$ Pravni pisci su smatrali da postojanje ovakve odredbe nije dovoljno, već da je treba značajno upotpuniti. Tako, na primer, Jankovec ukazuje da nije određeno da pomenuti organ ima pravo da zabrani privrednoj organizaciji ugovaranje takvih klauzula i nije predviđeno da nepoštovanje takve zabrane predstavlja privredni prestup $^{19}$. Ovakva izričita zakonska odredba nije sadržana u važećem Zakonu o trgovini, a oblast zaštite potrošača danas je uređena posebnim zakonom. ${ }^{20}$

O upravnoj kontroli se može govoriti i u kontekstu upravne kontrole pravičnosti odredaba koje su sadržane u OUP. Pojedini pravni pisci o ulozi organa uprave (barem u regionu) u vezi sa upravnom kontrolom nepravičnih odredaba govore sa tri aspekta: (1) učešće u pregovorima i davanje smernica; (2) istražna ovlašćenja državnih organa i (3) ovlašćenja javnih organa da izdaju naloge. ${ }^{21} \mathrm{U}$

17 Tada administrativna vlast počinje da preduzima izvesne mere u cilju zaštite ekonomski slabijih pojedinaca, pravdajući to idejom javnog interesa, pa tako ona počinje npr. da vodi nadzor nad uslovima pod kojima radnici rade u pojedinim preduzećima, obraća pažnju na rad velikih preduzeća koja uživaju faktički monopol i na njihovo držanje prema potrošačima. Detaljnije: Blagojević, B., 1934, Ugovori po pristanku - formularni ugovori (doktorska rasprava), Beograd, Pravni fakultet Univerziteta u Beogradu, str. 81.

18 Član 39. stav 1. Zakona o trgovini (Sl. list SRJ, br. 32/93): Savezno ministarstvo nadležno za poslove trgovine prati stanje $u$ oblasti zaštite potrošača $i$, na zahtev potrošača ili na sopstvenu inicijativu, utvrđuje da li formularni ugovori sadrže klauzule kojima se narušava ravnopravnost saugovarača i preduzima mere za zaštitu potrošača, naročito u pogledu kvaliteta i cene robe i u pogledu trgovinskih usluga.

19 Videti: Jankovec, I., 1997, Sudska kontrola opštih uslova poslovanja, u: Borislav T. Blagojević, Niš, Pravni fakultet Univerziteta u Nišu - Institut za pravna i društvena istraživanja, str. 34.

20 Videti: Zakon o zaštiti potrošača, Sl. glasnik RS, br. 62/14, 6/16 - dr. zakon i 44/2018 - dr. zakon.

21 Ovlašćenje da izdaje naloge u našoj državi pripada inspektoru u okviru inspekcijskog nadzora, a ovakva ovlašćenja poznaju i druge države i ona pripadaju pojedinim subjektima koji su odgovorni za zaštitu potrošača prema sistemu koji je primenjen u određenoj državi. Tako, na 
pogledu preporuka i smernica, što bi se moglo smatrati svojevrsnom prethodnom kontrolom, regionalna iskustva pokazuju da treba razmotriti mogućnost da državne institucije učestvuju u pregovorima i daju smernice u pogledu pravičnosti opštih uslova formularnih potrošačkih ugovora. ${ }^{22}$ Takva mogućnost postoji u Bosni i Hercegovini, gde je dužnost ombudsmana za zaštitu potrošača da preporučuje upotrebu određenih standardnih ugovornih odredaba u ugovorima koji se koriste u posebnim sektorima poslovanja, kao i da pregovara s predstavnicima određenih trgovinskih udruženja o modelima ugovora koji se primenjuju u specifičnim sektorima poslovanja, dok u Albaniji ministarstva u čiju nadležnost spadaju poslovi iz oblasti ekonomije, trgovine i energetike učestvuju u izradi kodeksa ponašanja i tipskih ugovora, u saradnji sa privrednim subjektima. ${ }^{23}$ Mehanizmi koji postoje u Crnoj Gori, a koji se mogu primeniti u slučaju nepravičnih opštih uslova formularnih potrošačkih ugovora odnose se na: crnogorsko ministarstvo nadležno za poslove zaštite potrošača koje proučava i daje predloge koji se odnose na potrošače i politiku zaštite potrošača; vansudsku zaštitu koja se ostvaruje preko Arbitražnog odbora za vansudsko rešavanje sporova potrošača, kao i na bankarskog ombudsmana koji daje preporuke bankama i mikrokreditnim finansijskim institucijama i kreditnim unijama za poboljšanje odnosa prema klijentima. ${ }^{24}$

$\mathrm{U}$ okvir upravne kontrole, tj. kontrole od strane upravnih organa, spada $\mathrm{i}$ nadzor nad sprovođenjem zakona i inspekcijski nadzor. Naš Zakon o zaštiti potrošača predviđa da nadzor nad sprovođenjem ovog zakona i propisa donetih na osnovu ovog zakona vrši ministarstvo nadležno za zaštitu potrošača, kao i da organi državne uprave i organi autonomne pokrajine i jedinice lokalne samouprave u delokrugu obavljanja svojih poslova vrše nadzor nad sprovođenjem propisa u oblasti zaštite potrošača i preduzimaju radnje propisane ovim zakonom i drugim propisima. Inspekcijski nadzor nad sprovođenjem ovog zakona i propisa donetih na osnovu ovog zakona vrši ministarstvo nadležno za poslove trgovine, preko tržišnih inspektora, kao i ministarstvo nadležno za poslove turizma, preko

primer, u Albaniji (pored sudova) ovlašćenje da trgovcima izdaje naloge u pogledu nepravičnih odredaba u potrošačkim ugovorima ima i Komisija za zaštitu potrošača, a u Bosni i Hercegovini je propisana dužnost ombudsmana za zaštitu potrošača da donosi odluke i preduzima druge mere u slučajevima pritužbi potrošača ili kršenja dobrih poslovnih običaja, te ima i nadležnost da izdaje instrukcije za prestanak aktivnosti koje su u suprotnosti sa potrošačkom legislativom i da iznosi te instrukcije pred sud. Detaljnije: Karanikić Mirić, M., Čađenović, Z., 2010, Transponovanje pojedinih direktiva: Direktiva o nepravičnim ugovornim odredbama (93/13), u: Civil Law Forum for South East Europe: Collection of studies and analyses - First Regional Conference, Deutsche Gesellschaft für Technische Zusammenarbeit: Offener Regionalfonds für Südosteuropa -Rechtsreform, Cavtat, Vol. III, str. 650-651, koji na istom mestu ukazuju da u nekim od zemalja u okruženju, osim inspektora, određeni državni organi imaju određena istražna ovlašćenja, pa tako navode da Ombudsman za zaštitu potrošača u Bosni i Hercegovini ima dužnost da istražuje aktivnosti na tržištu usmerene prema potrošaču po službenoj dužnosti i po osnovu žalbe, kao i da istražna ovlašćenja ima i organ nadležan za nadzor nad tržištem u Albaniji.

22 Karanikić Mirić, M., Čađenović, Z., 2010, str. 650.

23 Ibid.

24 Ibid. 
turističkih inspektora, u skladu sa ovlašćenjima propisanim ovim zakonom i propisima kojima se uređuje inspekcijski nadzor u ovim oblastima. ${ }^{25}$

Zakonom o zaštiti potrošača predviđena je nadležnost ministarstva nadležnog za zaštitu potrošača ${ }^{26}$ za pokretanje i vođenje postupka za zaštitu kolektivnih interesa potrošača ${ }^{27}$ u okviru koga se ispituje i pravičnost ugovornih odredaba. Ako se utvrdi postojanje povrede kolektivnog interesa, može se, između ostalog, izreći mera obustavljanja ugovaranja nepravičnih ugovornih odredaba. Konkretno, prema zakonskom određenju, povreda kolektivnog interesa potrošača, između ostalog, postoji u slučaju nepoštene poslovne prakse, odnosno nepravičnih odredaba u potrošačkim ugovorima. ${ }^{28}$ Postupak zaštite kolektivnog interesa pokreće i vodi ministarstvo, po zahtevu ovlašćenog lica ili po službenoj dužnosti. Ako u postupku nadzora ministarstvo oceni da neko činjenje ili nečinjenje učesnika na tržištu, a posebno postojanje nepoštene ugovorne odredbe ili nepoštene poslovne prakse, ugrožava ili preti da ugrozi kolektivni interes potrošača, pokrenuće postupak utvrđivanja povrede kolektivnog interesa potrošača po službenoj dužnosti. ${ }^{29} \mathrm{U}$ pogledu odluke o postupku zaštite kolektivnog interesa

25 U vršenju inspekcijskog nadzora nadležni inspektor ima sva prava, dužnosti i ovlašćenja koja su propisana ovim zakonom i zakonima kojima se uređuje inspekcijski nadzor u oblasti trgovine, odnosno turizma. U slučaju utvrđivanja povrede zakona inspektor nalaže trgovcu, odnosno prodavcu da otkloni utvrđenu nepravilnost. Inspektor će rešenjem odrediti i rok u kojem će trgovac, odnosno prodavac biti dužan da otkloni nepravilnost, a koji ne može biti kraći od 24 sata niti duži od dva meseca, ako drugačije nije propisano. Ako trgovac, odnosno prodavac ne postupi po ovom nalogu, inspektor će rešenjem izreći meru privremene zabrane prometa robe, odnosno vršenja usluge na koju se mera odnosi. Videti član 157. Zakona o zaštiti potrošača. Inspekcijski nadzor u smislu ovog zakona vrši se po službenoj dužnosti i započinje preduzimanjem prve radnje inspektora u postupku inspekcijskog nadzora. Prijave povrede zakona, odnosno druge informacije, dojave, podnesci i zahtevi podneti radi preduzimanja inspekcijskog nadzora imaju dejstvo inicijative za pokretanje postupka, a podnosioci tih inicijativa nemaju svojstvo stranke $u$ postupku. O svim radnjama u postupku inspekcijskog nadzora od značaja za utvrđivanje činjeničnog stanja inspektor sastavlja zapisnik. O pitanjima koja nisu od neposrednog značaja za utvrđivanje činjeničnog stanja inspektor sastavlja službenu belešku. Ako utvrdi povredu zakona, inspektor donosi i dostavlja rešenje u skladu sa svojim ovlašćenjem u roku od pet dana od dana otpočinjanja, odnosno okončanja kontrole. Protiv ovog rešenja može se izjaviti žalba u roku od osam dana ministru, koja ne odlaže izvršenje rešenja. Protiv drugostepene odluke ministra stranka kojoj je izrečena upravna mera može da pokrene postupak pred Upravnim sudom u roku od 14 dana, ali žalba ne odlaže izvršenje rešenja. Videti čl. 158-159. Zakona o zaštiti potrošača.

26 U ovom trenutku, u Republici Srbiji je za zaštitu potrošača nadležno Ministarstvo trgovine, turizma i telekomunikacija, u okviru koga postoji poseban Sektor za zaštitu potrošača. Videti: https://mtt.gov.rs/sektori/sektor-za-zastitu-potrosaca/.

27 ZZP sadrži posebne odredbe (čl. 145-153) o zaštiti kolektivnog interesa potrošača. Detaljno o ovom vidu zaštite potrošača: Jovičić, K., Dabetić-Trogrlić, V., 2016, Komentar Zakona o zaštiti potrošača, Glosarijum, Beograd, str. 325-348.

28 Videti član 145. stav 1. tačka 2. Zakona o zaštiti potrošača.

29 Ministarstvo pokreće postupak zaštite kolektivnog interesa potrošača po službenoj dužnosti kada na osnovu dostavljenih inicijativa, informacija i drugih raspoloživih podataka, oceni postojanje povrede kolektivnog interesa potrošača. U postupku zaštite kolektivnog interesa primenjuju se pravila opšteg upravnog postupka, ako ovim zakonom nije drugačije propisano. Videti član 146. ZZP-a. Zahtev za zaštitu kolektivnog interesa potrošača mogu da podnesu evidentirana udruženja, odnosno savezi iz člana 132. ovog zakona. Videti član 147. ZZP-a. 
potrošača, ministarstvo rešenjem odlučuje o postojanju povrede i određivanju mere, pri čemu rešenje sadrži i rok za sprovođenje izrečene mere, ${ }^{30} \mathrm{a}$ istim rešenjem ministarstvo može trgovcu da naloži obavezu da u utvrđenom roku izvesti ministarstvo o sprovođenju izrečenih mera. ${ }^{31}$ Član 149. ZZP-a propisuje da lice protiv kojeg se vodi postupak može u svom odgovoru dati predlog obaveza koje je spremno da preduzme radi otklanjanja povrede zakona, sa uslovima i rokovima za sprovođenje (korektivna izjava). Ako je utvrđeno postojanje povrede kolektivnog interesa, određuje se mera zaštite kolektivnog interesa potrošača, kojom se može naložiti licu protiv koga je vođen postupak da preduzme određeno ponašanje ili da mu se zabrani određeno ponašanje, a naročito da: (1) prekine sa kršenjem odredaba ovog zakona ili drugog propisa kojim se ugrožava kolektivni interes potrošača i uzdrži se od toga ubuduće; (2) da otkloni utvrđenu nepravilnost; (3) prestane sa nepoštenom poslovnom praksom i da mu zabrani takvo ili slično postupanje ubuduće; (4) bez odlaganja obustavi ugovaranje nepravičnih ugovornih odredaba. Rešenje kojim se određuje neka od navedenih mera objavljuje se na internet stranici ministarstva. ${ }^{32}$ Ako postoji opasnost od nastupanja štetnih posledica po prava i interese potrošača, ministarstvo, na predlog podnosioca zahteva, može da naloži prestanak vršenja određenih radnji, odnosno obavezu preduzimanja radnji kojima se sprečavaju ili otklanjaju štetne posledice. ${ }^{33}$

$\mathrm{Na}$ internet prezentaciji ministarstva redovno se javno objavljuju doneta rešenja o povredi kolektivnog interesa potrošača, koja uključuju i zabranu daljeg korišćenja nepravičnih ugovornih odredaba. Na ovaj način ministarstvo postiže dvostruko dejstvo, tj. dvojaku svrhu donošenja rešenja i objavljivanja: osim reaktivnog dejstva za trgovca (stranke) u konkretnom slučaju u kome je u predviđenom postupku utvrđena povreda kolektivnog interesa potrošača, javno objavljivanje primerom preventivno deluje na ostale učesnike na tržištu da ne primenjuju nepravične ugovorne odredbe. ${ }^{34}$

30 Član 149. stav 2. ZZP-a propisuje da će Ministarstvo obavestiti lice protiv kojeg je pokrenut postupak zaštite kolektivnog interesa potrošača o bitnim činjenicama, dokazima i ostalim elementima zbog kojih se postupak vodi i pozvati da se izjasni u roku od 15 dana od dana prijema ovog obaveštenja.

31 Videti član 150. stav 2. ZZP-a.

32 Ukoliko ministarstvo utvrdi da je došlo do povrede kolektivnog interesa potrošača, podnosi zahtev za pokretanje prekršajnog postupka nadležnom organu, za prekršaje predviđene ovim zakonom. Videti član 150. ZZP-a.

33 Ovakva privremena mera može da traje do donošenja rešenja u tom postupku. Videti član 151. ZZP-a. Ministarstvo prekida postupak ako se trgovac korektivnom izjavom obaveže da neće nastaviti ili ponoviti radnju ili akt kojim se šteti kolektivnom interesu potrošača, a prekid postupka može da traje najduže tri meseca. Ako stranka protiv koje se vodi postupak ne ispuni ili prekrši preuzete obaveze pre isteka roka od tri meseca ili u međuvremenu učini novu povredu, Ministarstvo nastavlja postupak. Ako stranka protiv koje se vodi postupak ispuni preuzete obaveze u propisanom roku, Ministarstvo će obustaviti postupak. Pokretanje ili vođenje postupka za zaštitu kolektivnog interesa potrošača ne sprečava potrošača kome je prouzrokovana šteta da pokrene pred nadležnim sudom postupak za naknadu te štete ili da pred sudom pokrene postupak za poništaj ili utvrđivanje ništavosti ugovora, odnosno da pred sudom pokrene bilo koji drugi postupak zahtevajući ostvarenje svojih prava. Videti čl. 152-153. ZZP-a.

34 Vukadinović, S., 2019, str. 318. 
Tokom 2018. godine Ministarstvo trgovine, turizma i telekomunikacija donelo je tri rešenja koja se odnose na odredbe sadržane u opštim uslovima poslovanja. Ministarstvo je donelo rešenje kojim je utvrdilo da je Telenor d.o.o. učinio povredu kolektivnog interesa potrošača tako što u Opštim uslovima pružanja i korišćenja usluga u javnoj mobilnoj komunikacionoj mreži, ${ }^{35} \mathrm{u}$ članu 11. stav 2. ugovara nepravičnu ugovornu odredbu u korist trgovca, propisujući da se naknada štete koju se pretplatnik obavezuje da Telenoru isplati zbog prevremenog raskida ugovora utvrđuje u iznosu koji odgovara zbiru svih preostalih mesečnih pretplata počev od raskida pretplatničkog ugovora do isteka inicijalno ugovorenog obaveznog trajanja pretplatničkog odnosa za izabrani tarifni paket ukoliko pretplatnik raskine ili uzrokuje raskid pretplatničkog ugovora pre isteka perioda na koji je zaključen. Istim rešenjem, Ministarstvo je naložilo imenovanom pravnom licu da obustavi ugovaranje navedene odredbe Opštih uslova za koju je utvrđeno da predstavlja nepravičnu ugovornu odredbu. ${ }^{36}$

Nadalje, Ministarstvo je donelo rešenje kojim utvrđuje da je „Brunata“ d.o.o. učinila povredu kolektivnog interesa potrošača tako što obmanjujućom poslovnom praksom daje netačna obaveštenja potrošačima o njihovim pravima na taj način što je odredbom člana 8.5. Opštih uslova prodaje i isporuke i članom 13. Ugovora o isporuci i ugradnji delitelja toplote i očitavanja potrošnje propisala da prima reklamacije potrošača samo u pismenoj formi. Istim rešenjem je naloženo imenovanom pravnom licu da prestane sa nepoštenom poslovnom praksom i zabranjeno mu je ugovaranje navedenih odredaba. ${ }^{37}$

Ministarstvo je donelo i rešenje kojim utvrđuje da je VIP Mobile d.o.o. učinilo povredu kolektivnog interesa potrošača tako što u Opštim uslovima ugovora o pretplatničkom i korisničkom odnosu mobilne telekomunikacione mreže, ${ }^{38}$ u članu 17. stav 1. ugovara nepravičnu odredbu u korist trgovca, propisujući da u slučaju da pretplatnik raskine ili svojim ponašanjem dovede do raskida, odnosno prestanka pretplatničkog odnosa pre isteka minimalnog predviđenog perioda njegovog trajanja, pretplatnik se obavezuje da plati VIP-u ugovornu kaznu zbog neizvršenja ugovorne obaveze, $u$ iznosu svih preostalih mesečnih pretplata počev od dana raskida pretplatničkog odnosa do dana isteka minimalnog predviđenog perioda njegovog trajanja, dakle obavezuje potrošača koji je povredio ugovornu obavezu da trgovcu plati naknadu u iznosu koji značajno premašuje iznos pretrpljene štete. ${ }^{39}$ Istim rešenjem je imenovanom pravnom licu naloženo da obustavi ugovaranje citirane odredbe svojih Opštih uslova, koja predstavlja nepoštenu ugovornu odredbu. ${ }^{40}$

35 Telenor d.o.o. Beograd, koji su počeli da se primenjuju dana 9. 12. 2015. godine i dalje.

36 Rešenje Ministarstva trgovine, turizma i telekomunikacija broj: 330-00-00028/2018-11 od 12. juna 2018. godine.

37 Rešenje Ministarstva trgovine, turizma i telekomunikacija broj: 330-00-00091/2016-11 od 4. juna 2018. godine.

38 Koji su počeli da se primenjuju dana 17. 6. 2017. godine i dalje.

39 Rešenje Ministarstva trgovine, turizma i telekomunikacija broj: 330-00-00019/2015-11 od 14. maja 2018. godine.

40 Sva citirana rešenja, kao i rešenja iz prethodnih godina, dostupna su na internet adresi: http:// mtt.gov.rs/informacije/zastita-potrosaca/resenje-o-povredi-kolektivnog-interesa-potrosaca/. 
Imajući u vidu aktuelne mogućnosti zaštite kolektivnog interesa potrošača od nepoštenih ugovornih odredaba u Srbiji, čini se da je analizirani mehanizam, kao postupak koji vodi Ministarstvo (MTTT) najdelotvorniji, kao i da je dobro što su rešenja koje je MTTT donelo javno objavljena i dostupna, jer se tako osim kolektivne zaštite povodom konkretne nepravične odredbe određenog lica, povodom koje je rešenje doneto, može računati u određenoj meri i na preventivno dejstvo koje se ogleda u očekivanom efektu odvraćanja drugih lica da slične odredbe predviđaju svojim tipskim ugovorima i opštim uslovima.

Pravna teorija danas često ukazuje na efikasnost upravnopravne zaštite, sa argumentacijom da je organ uprave, naročito ako je reč o organu koji vrši tržišni nadzor nad pojedinim tržištem, zbog činjenice poznavanja tržišta i poslovnih praksi (ekspert u datoj oblasti, posebno ako je reč o institucionalnom regulatornom telu, odnosno javnoj agenciji kao posebnom organu uprave) u prednosti u poređenju sa sudovima, te da na taj način nadzor nad tržištem od strane uprave predstavlja ne samo efikasniji već i jeftiniji model koji ima bolju preventivnu ulogu u odnosu na sudsku zaštitu, a ima i mogućnost brzog reagovanja. ${ }^{41}$

\section{TRŽIŠNI NADZOR OD STRANE NEZAVISNIH ILI „POLUNEZAVISNIH“ DRŽAVNIH ORGANA I SPECIJALIZOVANI OMBUDSMANI}

Savremeno pravo poznaje i posebne specijalizovane organe koji obavljaju ulogu nadzora nad tržištem ili je ta uloga pridodata organima koji imaju i druge nadležnosti, npr. onima koji su nadležni i za zaštitu konkurencije (tzv. antimonopolska tela). Njihov odnos prema izvršnoj grani vlasti je različito postavljen - od toga da su oni sastavni deo upravnih ograna, do polunezavisnog položaja kroz određena savetodavna ili regulatorna tela, odbore, javne agencije, do samostalnog i nezavisnog položaja posebnih državnih organa. Prethodno pomenuta tela prof. dr Tatjana Jovanić sistematizuje u tri organizaciona modela: nezavisne regulatorne agencije, organizacione jedinice pri nekom ministarstvu i specijalizovane vladine organizacije, istovremeno ukazujući da nezavisne javne agencije po pravilu imaju i finansijsku samostalnost, dok druga dva oblika često nemaju sopstvene izvore prihoda, već se finansiraju iz državnog budžeta. ${ }^{42}$ Postojanje, uloga, nadležnost $\mathrm{i}$ ovlašćenja ovakvih organa u uporednom pravu različiti su od države do države, a u kontekstu teme ovog rada zanimljivo je ukazati da je u Francuskoj pri ministarstvu nadležnom za zaštitu potrošača obrazovana Komisija za nepravične klauzule (fr. Commission des clauses abusives), ${ }^{43}$ koja pored

41 Jovanić, T., Uloga uprave u zaštiti kolektivnih interesa potrošača, u: Bourgoignie, T., Jovanić, T. (eds.), 2013, Strengthening Consumer Protection in Serbia - Liber Amicorum Svetislav Taboroši, Beograd, Pravni fakultet Univerziteta u Beogradu, str. 313. Na istom mestu se ukazuje i na argumentaciju suprotnog stanovišta koje se zasniva na činjenici da nezavisno sudstvo umanjuje mogućnost pristrasnosti organa uprave.

42 Osim ukoliko nemaju mogućnost da zadrže deo novčanih sredstava koja potiču od kazni koje se izriču zbog povrede propisa. Tako: Jovanić, T., 2013, str. 318.

43 Internet prezentacija ove komisije dostupna je na adresi: http://www.clauses-abusives.fr. 
nadzora nad tržištem ima i savetodavnu ulogu. Komisija za nepravične klauzule nadgleda tržište i prati formularne ugovore, daje preporuke u vezi sa pojedinačnim ugovornim odredbama na svoju inicijativu ili na zahtev, dok na zahtev suda u postupku ocene pravičnosti ugovornih odredaba daje mišljenje. ${ }^{44}$

U pojedinim zemljama, kao na primer u Australiji, isto telo je zaduženo i za zaštitu konkurencije i za zaštitu potrošača. Australijska komisija za konkurenciju i potrošače ${ }^{45} \mathrm{u}$ okviru nepoštene poslovne prakse obuhvata i nepravične ugovorne odredbe, ${ }^{46} \mathrm{u}$ vezi sa kojima potrošači mogu podneti pritužbu ovoj komisiji, s tim da pre podnošenja pritužbe ovoj komisiji treba da se obrate, tj. da kontaktiraju sa prodavcem, odnosno sa pružaocem usluge bilo usmeno bilo pismeno. Komisija usmerava, pruža pomoć i savete, ali ne rešava pojedinačne slučajeve, već su za njih nadležni sudovi za sporove male vrednosti čiji je spisak, po teritorijalnom principu, dostupan na sajtu ove komisije. ${ }^{47}$ Ono što je specifičnost Australije jeste da postoji čitav sistem (mreža) sektorskih industrijskih ombudsmana i poverenika koji pomažu u rešavanju sporova u posebnim oblastima privrede. Tako je jula 2012. godine ustanovljeno nezavisno telo pod nazivom Zastupnik (advokat) korisnika usluga avio-kompanija (dalje: ACA), koji predstavlja besplatan servis potrošača tako što pruža pomoć potrošačima u rešavanju nerešenih pritužbi potrošača na usluge koje pružaju avio-kompanije. Uloga ove službe jeste da efektivno predstavlja i zastupa interese korisnika avio-usluga, prosleđuje pritužbu nadležnim osobama i stara se da potrošač dobije odgovor u okviru razumnog roka, koji uobičajeno iznosi 20 dana. Avio-kompanije su dužne da blagovremeno odgovore na sve pritužbe koje ova služba dostavi. Osim na pojedinačnom nivou, gde ovo telo svakom potrošaču omogućava i da onlajn prati status rešavanja svoje pritužbe, ACA sistemski doprinosi podizanju nivoa standarda potrošačkih usluga u avio-sektoru tako što prati stanje i izveštava o pritužbama koje prima i pitanjima koja se otvaraju, javno objavljuje godišnje izveštaje, može uputiti preporuku pojedinačnoj avio-kompaniji za unapređenje usluge i odnosa sa potrošačima, identifikuje sistemska pitanja koja mogu voditi ka širim preporukama za promene. ${ }^{48}$ Ovaj organ je na svojoj veb-prezentaciji objavio i Potrošačku povelju ${ }^{49}$ i formular pritužbe koja se može podneti i onlajn na sajtu, kao i putem mejla. Kada se uzme u obzir podatak da su potrošači u Australiji tokom 2018. godine kupili 80.669.316 avio-karata i da se taj broj svake godine uvećava, a uvećava se i broj pritužbi, moglo bi se zaključiti da su ova specijalizovana tela obrazovana u onim sektorima u kojima potrošači masovno zaključuju ugovore, s tim da je u vezi sa

44 Jovanić, T., 2013, str. 322, koja na istom mestu (fn. 52) kao interesantnu navodi činjenicu da u sastav ove komisije, pored profesionalnih državnih službenika, ulaze i predstavnici regulisanih profesija, trgovaca, kao i predstavnici potrošačkih organizacija.

45 https://www.accc.gov.au.

$46 \mathrm{https} / / / \mathrm{www}$.accc.gov.au/business/treating-customers-fairly/unfair-business-practices\#unfaircontract-terms.

47 https://www.accc.gov.au/contact-us/other-helpful-agencies/small-claims-tribunals.

48 U tom smislu je opšti cilj ovog tela kako da dođe do smanjenja broja pritužbi uopšte, tako i do smanjenja broja pritužbi po kojima je neadekvatno postupljeno. Detaljnije: http://www. airlinecustomeradvocate.com.au/General/AboutUs.aspx.

49 http://www.airlinecustomeradvocate.com.au/General/ACACustomerCharter.aspx. 
avio-saobraćajem potrošačima često i potrebna pomoć zbog primene međunarodnih konvencija, kao i zbog komplikacija do kojih dolazi u vezi sa izgubljenim prtljagom i naknadama zbog kašnjenja letova, zahtevima za refundaciju, kao i da se australijski Zakon o zaštiti potrošača primenjuje i na korisnike usluga avio-saobraćaja. Tokom 2018. godine, ACA je primila ukupno 1410 pritužbi, od čega je finalizovano 1406 (99,7\%), a rešeno ${ }^{50} 994$ (70,7\%), dok je istovremeno primljeno i 2135 telefonskih poziva kada je ACA dala informacije o svojoj ulozi u rešavanju predstavki. Prosečno vreme rešavanja pritužbe je kraće od propisanih 20 dana na koje su se avio-kompanije obavezale i iznosi 17 dana, pri čemu $85,66 \%$ potrošača ocenjuje da je po njihovoj pritužbi postupljeno blagovremeno. ${ }^{51}$

Pored navedenog, u Australiji postoji Ombudsman industrije telekomunikacija, koji preko $90 \%$ pritužbi rešava u okviru 10 radnih dana, odnosno već u prvoj fazi u kojoj ovaj ombudsman, povodom podnete pritužbe, kontaktira sa pružaocem telekomunikacionih usluga. ${ }^{52}$ Prema poslednjem objavljenom izveštaju, ovaj specijalizovani ombudsman godišnje primi 132.387 pritužbi, od čega se $32,6 \%$ odnosi na usluge interneta, a $30,3 \%$ na usluge mobilne telefonije. ${ }^{53}$ Ovaj ombudsman postupa i po pritužbama malih preduzeća, čije pritužbe čine $14,5 \%$ ukupnog broja godišnjih pritužbi. Ono što je od posebnog značaja za kolektivnu zaštitu jeste to da se ovaj ombudsman bavi i sistemskim pitanjima, odnosno ima sistemska ovlašćenja, što mu omogućava da identifikuje probleme u vezi sa procesima i praksom telekomunikacione industrije u celini, kao i probleme koji mogu prouzrokovati štetu potrošačima i malim preduzećima. Istražujući probleme, podižući svest i radeći sa pružaocima telekomunikacionih usluga na sprovođenju promena koje preporučuje, Ombudsman industrije telekomunikacija pokreće poboljšanja u pružanju telekomunikacionih usluga što dovodi do boljih rezultata i za potrošače i za telekomunikacionu industriju. $U$ tom smislu i u vezi sa sistemskim pitanjima, ovaj specijalizovani ombudsman je objavio više sistemskih izveštaja (npr. Uticaj COVID-19 na pritužbe na telefon i internet, Rešavanje uzroka žalbi malih preduzeća, Obmanjujuće telemarketing usluge, Smanjenje krađa mobilnih brojeva od strane prevaranata, itd.) i više sistemskih studija slučaja (npr. Neobične mobilne nadogradnje, Obmanjujući pozivi za prodaju usluga i sl.). ${ }^{54}$ Pored navedenih specijalizovanih ombudsmana, postoji i Australijsko telo za finansijske pritužbe, kome potrošači i mala preduzeća mogu podneti finansijsku pritužbu koja se odnosi na bankarski i sektor osiguranja. Ovo telo je uspostavljeno 1. novembra 2018. godine transformacijom dotadašnje Službe finansijskog ombudsmana. ${ }^{55}$

50 Rešenim se smatraju pritužbe za koje potrošač smatra da su rešene, ukoliko je zahtev potrošača iz pritužbe ponuđen od strane avio-kompanije i prihvaćen od strane potrošača ili ukoliko je avio-kompanija uputila predlog (ponudu) koju je potrošač prihvatio.

51 Podaci iz godišnjeg izveštaja ACA za 2018. godinu, (http://www.airlinecustomeradvocate. com.au/_lib/Docs/AnnualReport/Annual_Report_2018.pdf).

52 https://www.tio.com.au.

53 Izveštaj se odnosi na period od 1. jula 2018. godine do 30. juna 2019. godine, (https://www. tio.com.au/reports-updates/annual-report-2018-19).

54 https://www.tio.com.au/systemic-issues.

55 https://www.afca.org.au. 
Pored različitih komisija i agencija, posebnu pažnju pravnih pisaca je zbog postizanja efikasne zaštite potrošača privukao skandinavski model potrošačkog ombudsmana, tj. institucija specijalizovanog ombudsmana za zaštitu potrošača. Iako postoje razlike u pogledu načina njihovog osnivanja, finansiranja, organizovanja, načina postupanja, prirode i obima ovlašćenja koja su im data, ovaj institut je pokazao pozitivne efekte u zaštiti potrošača u državama u kojima postoji, zbog čega se prof. dr Katarina Ivančević zalaže da se i u Republici Srbiji radi uspostavljanja specijalizovanih ombudsmana za zaštitu potrošača i država i privrednici organizuju po skandinavskom modelu. ${ }^{56}$

U Švedskoj, ${ }^{57}$ Finskoj, Danskoj i Norveškoj, potrošački ombudsman obavlja javnu funkciju, bira ga parlament, finansira se iz budžeta, a osnovni zadatak je nadzor nad primenom zakona na tržištu i formiranje dobre prakse ponuđača roba i usluga, zbog čega se ovi ombudsmani ne bave konkretnim pojedinačnim zahtevima potrošača $i$, po pravilu, ne rešavaju potrošačke sporove, već su formirani sa ciljem da zaštite kolektivne interese potrošača. ${ }^{58}$

Švedska potrošačka agencija je vladina agencija odgovorna Ministarstvu poljoprivrede, hrane i zaštite potrošača, čiji je generalni direktor istovremeno i ombudsman za zaštitu potrošača i on je najviše usmeren na zaštitu ekonomskih interesa potrošača u domenu fer trgovačke prakse. Agencija, odnosno Ombudsman ima mogućnost davanja preporuka i sugestija trgovcima, te u slučaju da po njima ne postupe, Ombudsman može pokrenuti postupak u kome zastupa interes potrošača ${ }^{59}$ Pored toga što štiti interese potrošača posebno u pogledu sigurnosti roba i usluga, reklama i uslova ugovora, Agencija sprovodi i obuku opštinskih savetnika za potrošačka pitanja i savetnika za pitanja budžeta i dugova. Švedski potrošački ombudsman pokreće postupke na osnovu direktnih prijava potrošača, onih koje su mu upućene posredno preko savetovališta za potrošače koja rade pri opštinskim upravama i na osnovu sopstvenih saznanja koja stiče prateći dešavanja na tržištu, a aktivnost ombudsmana je usmerena i na sprečavanje korišćenja nepoštenih odredaba u opštim uslovima i potrošačkim ugovorima. ${ }^{60}$

56 Ivančević, K., 2013, Specijalizovani ombudsman za zaštitu potrošača, Pravo i privreda, 4-6, str. 342 i 355.

57 Imajući u vidu činjenicu da je ombudsman kao institucija prvi put uveden u Švedskoj Ustavom iz 1809. godine, zatim u drugim skandinavskim zemljama: Finskoj Ustavom iz 1919. godine, zatim Danskoj 1953. godine, pa u Norveškoj 1962. godine, ne čudi činjenica da je prva Kancelarija ombudsmana za zaštitu potrošača osnovana upravo u Švedskoj 1971. godine, a u Norveškoj Ombudsman za zaštitu potrošača 1972. godine, nakon čega i druge evropske države slede ovaj put skandinavskih država.

58 Izuzetak predstavlja finski Ombudsman koji pomaže individualnom potrošaču ukoliko se na taj način indirektno odlučuje i o generalnom interesu potrošača, odnosno o važnom aspektu politike zaštite potrošača. Detaljnije, sa pregledom posebnih tela koja rešavaju pojedinačne žalbe i potrošačke sporove (kao što je Nacionalni odbor za potrošačke sporove) videti: Ivančević, K., 2013, str. 344.

59 Jovanić, T., Uloga uprave u zaštiti kolektivnih interesa potrošača, u: Bourgoignie, T., Jovanić, T., (eds.), 2013, Strengthening Consumer Protection in Serbia - Liber Amicorum Svetislav Taboroši, Beograd, Pravni fakultet Univerziteta u Beogradu, str. 319.

60 Ivančević, K., 2013, str. 344-345. 
U Norveškoj, Potrošačkog ombudsmana imenuje vlada, ali on je nezavisan organ koji vrši nadzor nad sprovođenjem propisa iz oblasti nadzora nad tržištem. Potrošački ombudsman u Norveškoj je ovlašćen da donosi odluke o zabrani nezakonitog i nepoštenog poslovanja i ima mogućnost da izriče određene mere, protiv kojih se može izjaviti žalba Tržišnom savetu. ${ }^{61}$ Ovaj specijalizovani ombudsman u Norveškoj ima ovlašćenja da donosi odluke o zabrani upotrebe nepoštenih odredaba ugovora i opštih uslova ugovora kada smatra da je to neophodno u interesu potrošača i kada proceni da bi čekanje odluke Tržišnog saveta nanelo štetu potrošačima. ${ }^{62}$ Bosna i Hercegovina je 2006. godine uvela institut potrošačkog ombudsmana u svoj pravni sistem i sistem zaštite potrošača ${ }^{63} \mathrm{Nje}$ gov rad je i pravna teorija pozitivno ocenila u smislu da je pokazao dobre rezultate. ${ }^{64}$ Između ostalog, zakonska obaveza Ombudsmana za zaštitu potrošača u Bosni i Hercegovini je da preporučuje upotrebu određenih uslova ugovora u ugovorima koji se koriste u posebnim sektorima poslovanja, kao i da pregovara sa predstavnicima određenih trgovinskih udruženja o modelima ugovora koji se primenjuju u specifičnim sektorima poslovanja. ${ }^{65}$

Specijalizovani ombudsmani (zaštitnici prava) za određene sektore privrede, naročito u oblasti osiguranja, imaju različita ovlašćenja, ${ }^{66}$ među kojima neki i nadzor nad tržištem ili nadzor nad primenom kodeksa ponašanja, tj. kodeksa poslovne etike, što uključuje i odredbe opštih uslova poslovanja koji se primenjuju na ugovore u tim sektorima. Specijalizovani ombudsmani postoje u: Velikoj Britaniji, Nemačkoj, Poljskoj, Slovačkoj, Sloveniji, Hrvatskoj, Republici Srpskoj. Stiče se utisak da u evropskim zemljama jača trend osnivanja specijalizovanih ombudsmana pa je tako 2012. godine u Mađarskoj uveden finansijski ombudsman.${ }^{67} \mathrm{U}$ uporednom pravu postoje i drugi organi koji su od značaja za ovaj vid kontrole OUP, kao što su Odbor za pritužbe potrošača (u Švedskoj, Holandiji, Finskoj, Danskoj), odeljenja za pritužbe pri nadzornim organima (npr. u Španiji, Nemačkoj, Čileu, Sjedinjenim Američkim Državama itd.). ${ }^{68}$

U našem društvu je pitanje mogućeg uvođenja potrošačkog ombudsmana u Srbiji ponovo aktuelizovano poslednjih godina inicijativama udruženja građana i nevladinih organizacija, pa se tokom 2020. godine o ovoj ideji intenzivno

61 Jovanić, T., 2013, str. 319.

62 Ivančević, K., 2013, str. 345

63 Zakonom o zaštiti potrošača u Bosni i Hercegovini, Sl. glasnik BiH, br. 25/06 i 88/15. Videti čl. 100-105. ovog zakona.

64 Takvu ocenu daje: Jovanić, T., 2013, str. 318.

65 Član 101. stav 1. tačke f) i g) Zakona o zaštiti potrošača u Bosni i Hercegovini.

66 Pojedini specijalizovani ombudsmani u određenim državama imaju ulogu i u alernativnom načinu rešavanja potrošačkih sporova.

67 Nagy, Z., Somsák, S., 2019, The Micro-and Macro Level Instruments of financial consumer protection in Hungarian law, Zbornik radova Pravnog fakulteta u Novom Sadu, 4, str. 14371438.

68 Detaljno o navedenom videti doktorsku disertaciju: Ivančević, K., 2010, Pravna zaštita potrošača korisnika usluge osiguranja i bankarske usluge, Beograd, Pravni fakultet Univerziteta Union u Beogradu, str. 362-378. 
piše i u medijima. ${ }^{69}$ Potrošački ombudsman vidi se kao rešenje jer se u javnosti iznose ocene da položaj potrošača u Srbiji nije najpovoljniji, posebno u pogledu stvarne mogućnosti da zaštite svoja prava u konkretnim situacijama kada se javljaju njihove povrede ili ograničenja u postupcima trgovaca, pa se tako kao najčešći problemi sa kojima se potrošači suočavaju odnose na izostanak volje trgovaca da postupe po reklamacijama na robu ili usluge, česte nepoštene poslovne prakse i nepravične ugovorne odredbe, kao i kršenja obaveza trgovaca koji su pružaoci usluga od opšteg ekonomskog značaja. ${ }^{70} \mathrm{U}$ tom smislu su i u našem društvu ponovo aktuelizovani predlozi da bi Potrošački ombudsman, odnosno Zaštitnik potrošača kao organizacioni oblik bio naročito pogodan za davanje preporuka, smernica i drugih instruktivnih oblika uticaja na poslovne subjekte i njihove prakse, $u$ cilju pravilne primene propisanih prava potrošača $i$ unapređenja nivoa zaštite potrošača, dok bi mere koje su usmerene na sankcionisanje po pravilu podrazumevale učešće drugih organa i tela. ${ }^{71}$ Protić navodi da bi se postupak pred Zaštitnikom potrošača vodio po pritužbi građana ili po sopstvenoj inicijativi, a okončavao preporukom koja je usmerena na otklanjanje utvrđenog nedostatka. U nastavku objašnjava da bi se postupak inicirao potrošačkom pritužbom, koja bi se podnosila u slučaju prijema odbijenice nakon podnošenja reklamacije, odnosno u drugim situacijama kada se javlja povreda prava potrošača, a trgovac odbije da uvaži zahtev za otklanjanje nepravilnosti ili da ispuni svoju zakonsku obavezu. Ako se utvrdi da je zahtev potrošača osnovan, Zaštitnik potrošača bi preporukom tražio od trgovca ispunjavanje tog zahteva. U pogledu sankcija, sugeriše se mogućnost propisivanja prekršajne kazne za nepoštovanje preporuke, mogućnost javnog objavljivanja liste trgovaca koji ne poštuju te preporuke („stub srama“, „name and shame“ sistem), jer se ocenjuje da reputaciona šteta često predstavlja veću pretnju za trgovca od prekršajnih ili drugih sankcija, kao i da dejstvo objavljivanja slučajeva povreda prava potrošača iza kog stoji nezavisna institucija ima veći značaj nego kada to čine potrošačke organizacije ili pojedinci. ${ }^{72}$

69 Videti tekst: Zaštitnik potrošača - štit od svemoćnih trgovaca, objavljen 24. 6. 2020. u dnevnom listu Danas, (https://www.danas.rs/ekonomija/cep-zastitnik-potrosaca-stit-od-svemocnih-trgovaca/, 10. 9. 2020); tekst: Treba li Srbiji potrošački ombudsman, objavljen 28. 6. 2020. u dnevnom listu Politika, (http://www.politika.rs/scc/clanak/457269/Treba-li-Srbiji-potrosackiombudsman, 10. 9. 2020), kao i objave i blogove na drugim medijima tokom 2020. godine: https://www.dijalog.net/cep-zastitnik-potrosaca-karika-koja-nedostaje/; https://euractiv.rs/2srbija-i-eu/158-saoptenja/14714-potroai-u-srbiji-nemaju-oslonac-za-zatitu-svojih-prava; https://biznis.rs/vesti/zastitnik-prava-potrosaca-resenje-za-bolju-zastitu-potrosackih-pravau-srbiji/.

70 Lazarević, N., Ćirić, M., 2020, Zaštitnik potrošača- karika koja nedostaje, Centar za evropske politike - tekst objavljen 31. 7. 2020, (https://cep.org.rs/blogs/zastitnik-potrosaca-karika-koja-nedostaje/, 12. 9. 2020).

71 Protić, D., 2020, Zaštita potrošača u Srbiji: koji su mogući pravci napretka?, Centar za evropske politike, Beograd, str. 35 .

72 Protić, D., 2020, str. 35-36, koji u nastavku kao prednosti ističe: neformalan, efikasan postupak, uticaj na trgovce i njihove poslovne prakse putem preporuka, kao i uporedne modele i iskustva domaćih ombudsmanskih tela, dok kao nedostatke navodi organizacione i tehničke zahteve, kao i potencijalni teret velikog broja predmeta. 
Imajući u vidu činjenicu postojanja institucije Zaštitnika građana ${ }^{73} \mathrm{u}$ našem pravnom sistemu, možda bi se moglo alternativno raditi na tome da nadležnost Zaštitnika građana posebno obuhvati one nadležnosti koje imaju sektorski i specijalizovani ombudsmani u prethodno analiziranim državama, naročito skandinavskim. To bi se moglo realizovati tako što bi se ustanovio poseban sektor Zaštitnika građana $^{74}$ koji bi imao delokrug rada koji odgovara potrošačkom ombudsmanu i, između ostalog, vršio nadzor nad sprovođenjem odredaba opštih uslova poslovanja i davao preporuke u vezi sa njima. U ovom trenutku, a uzimajući u obzir aktuelne prilike u Srbiji, ovakvo rešenje bi u određenoj meri moglo biti ekonomičnije, ali se čini da bi ipak bilo delotvornije ako bi se išlo u pravcu uvođenja specijalizovanog ombudsmana za zaštitu potrošača, na način koji se već pokazao uspešnim u uporednom pravu. Kada je reč o uporednopravnom kontekstu, treba reći da u Sloveniji, Zakon o zaštiti potrošača izričito navodi Zaštitnika građana kao jednog od nosilaca zaštite potrošača, pored ministarstva nadležnog za privredu i potrošačkih organizacija. ${ }^{75}$ Zaštitnik građana u Sloveniji je ovlašćen da deluje i u oblasti zašitite potrošača, ali je njegovo delovanje na ovom polju ograničeno na odnose sa državnim organima, organima lokalne samouprave i nosiocima javnih ovlašćenja. ${ }^{76}$ Iako to znači da slovenački ombudsman nema direktna ovlašćenja nad privatnim subjektima u domenu povrede prava potrošača, njegovo iskustvo u radu pokazuje da se građani obraćaju ovom organu pritužbama u kojima ističu povrede prava potrošača, te da je ombudsman prosleđivao odgovarajuće slučajeve tržišnoj inspekciji, da je razmatrao i pratio način rada tržišne inspekcije, naročito $\mathrm{u}$ vezi sa sistemskim pitanjima, kao i da je u svom postupanju u cilju rešavanja sistemskih pitanja koja su se otvarala, osim tržišne inspekcije, uključivao i centralnu banku Slovenije u vezi sa pitanjima koja se odnose na postupanje poslovnih banaka prema korisnicima finansijskih usluga. ${ }^{77}$

Prema važećem pravnom okviru u Srbiji, delovanje Zaštitnika građana je usmereno na kontrolu rada organa državne uprave, organa nadležnog za pravnu zaštitu imovinskih prava i interesa Republike Srbije i drugih organa i organizacija, preduzeća i ustanova kojima su poverena javna ovlašćenja, ${ }^{78}$ te je u potencijalnom smislu zaštite kolektivnih interesa potrošača njegovo delovanje ograničeno.

73 Zanimljivo je pomenuti da je Zaštitnik građana tražio 8. 12. 2019. najpre izjašnjenje o opravdanosti angažovanja advokatskih kancelarija za prinudne naplate komunalnih usluga, a potom 24. 6. 2020. na osnovu informacija prikupljenih po sopstvenoj inicijativi uputio mišljenje kojim smatra da je angažovanje advokatskih kancelarija za prinudne naplate komunalnih usluga neopravdano. Detaljnije: https://ombudsman.rs/index.php/2011-12-11-11-34-45/6731-ngz-v-nj-dv-s-ih-nc-l-ri-z-prinudn-n-pl-un-lnih-uslug-p-inf-s-n-hn-l-gi-n-pr-vd-n.

74 Trenutna unutrašnja organizacija Zaštitnika građana je dostupna na: https://www.ombudsman.rs/index.php/o-nama/organizaciona-sema.

75 Čl. 61-65. Zakona o varstvu potrošnikov, Uradni list RS, št. 98/04 - uradno prečiščeno besedilo, 114/06 - ZUE, 126/07, 86/09, 78/11, 38/14, 19/15, 55/17 - ZKolT in 31/18, Slovenija.

76 Član 65. Zakona o varstvu potrošnikov (ZVPot), Slovenija.

77 Navedeni podaci su, kao odgovor na direktno obraćanje autora ovog rada, dobijeni putem elektronske pošte od ovlašćenog službenika slovenačkog ombudsmana.

78 Član 1. stav 1. Zakona o zaštitniku građana, Sl. glasnik RS, br. 79/05 i 54/07. 
Bez obzira na pitanje specijalizovanog ili kolegijalnog opšteg ombudsmana, imajući u vidu naš pravno-politički sistem, čini se da bi upravo status nezavisnog državnog organa obezbedio adekvatan autoritet specijalizovanom organu sa kojim bi on otpočeo svoju misiju na efektivan način. Takav položaj bi mu omogućio istinsku nezavisnost naročito u odnosu na izvršnu vlast, budući da je u aktuelnim prilikama isto ministarstvo nadležno i za trgovce i za potrošače, koji će se u slučaju sudskog spora naći na suprotstavljenim stranama. Kao nezavisni državni organ potrošački ombudsman (zaštitnik prava potrošača) bi za svoj rad polagao račun Narodnoj skupštini, koja bi razmatrala u plenumu godišnje izveštaje, a na sednicama matičnog odbora kvartalne izveštaje. Takvo redovno razmatranje izveštaja o radu i aktivno praćenje stanja u ovoj oblasti zakonodavcu bi omogućilo adekvatan i pravovremeni uvid, što stvara preduslov kako za jačanje kontrolne funkcije parlamenta u ovoj oblasti tako i za brže donošenje eventualnih novih propisa, odnosno izmenu i dopunu postojećih, a koji su od značaja za zaštitu potrošača. Nadležni odbor Narodne skupštine bi mogao da doprinese i održavanjem javnog slušanja na temu unapređenja kolektivne zaštite potrošača kako bi donosioci odluka saslušali i razmotrili sve argumente, kao i da se nakon toga povremeno održavaju kontrolna javna slušanja u cilju unapređenja stanja $u$ ovoj oblasti i vršenja parlamentarne kontrole.

$\mathrm{Na}$ opisani način potrošački ombudsman bi delovao na institucionalni način i zvaničnim putem, što bi moglo da ima i veći autoritet nego kada to čini udruženje potrošača. $U$ tom smislu nadležnost bi se, analogno nadležnostima u državama koje beleže dobru praksu ove institucije, odnosila ne samo na nepoštene ugovorne odredbe, nepoštenu poslovnu praksu, već i na redovno praćenje stanja i sagledavanje sistemskih problema na tržištu, sa aspekta prava potrošača, na osnovu čega bi mogao da izdaje preporuke za unapređenje, kako u pogledu praktičnih politika tako i u pogledu potreba za izmenom postojećih propisa ili donošenja novih. Tako, na primer, u našoj javnosti se neretko ističe problem sistematskog odbijanja reklamacija potrošača, te bi jedna od uloga potrošačkog ombudsman upravo bila da reaguje i na te situacije kako bi se izbegla poslednja mogućnost - da se ide na sud. Nadalje, potrošački ombudsman bi javnim objavljivanjem redovnih izveštaja imao i edukativnu ulogu, a programima edukacije i konkursima podsticao bi učešće pojedinaca i organizacija u razvoju i ostvarivanju prava potrošača. Takve aktivnosti bi doprinele i jačanju uloge obrazovanog društva. Pored sistemske uloge, da bi ovaj specijalizovani sektorski ombudsman bio efikasan, potrebno je da ima i odgovarajuća upravna i inspekcijska ovlašćenja, tj. da ima pravnu mogućnost i mehanizme da reaguje kako po obraćanju (prijavi, pritužbi) potrošača tako i po sopstvenoj inicijativi, odnosno po službenoj dužnosti kada ima određena saznanja.

Kada govorimo o ombudsmanima, onda je korisno imati u vidu i činjenicu da u Srbiji postoji i mogućnost osnivanja lokalnih ombudsmana na nivou jedinica lokalne samouprave, kao i da su pojedini gradovi i opštine u praksi ovu mogućnost i iskoristili. Analiza položaja lokalnih ombudsmana u Srbiji objavljena 2020. godine, $u$ delu analize povreda prava na koje se građani lokalnim ombudsmanima najčešće žale, svedoči da osobenosti pojedinih lokalnih ombudsmana 
predstavljaju pritužbe koje ne primaju drugi, između ostalog, povodom povrede prava potrošača. ${ }^{79}$ Imajući u vidu navedeno, kao i činjenicu da lokalne samouprave osnivaju komunalna preduzeća koja neretko koriste opšte uslove i tipske ugovore, te u vezi sa čijim radom građani podnose pritužbe, imalo bi smisla razmatrati mogućnost proširenja nadležnosti lokalnih ombudsmana.

Ovakva specifična mreža ombudsmana, tj. kombinacija proširenih ovlašćenja Zaštitnika građana i lokalnih ombudsmana možda bi mogla biti prelazno rešenje jer bi se koristili institucionalni i organizacioni kapaciteti koji već postoje, s tim da bi bilo neophodno izmeniti pravni okvir, tj. zakone, i obezbediti potrebna sredstva. U aktuelnom stanju i normativnom okviru u Srbiji, značajno ograničenje moguće uloge lokalnog ombudsmana (opšteg tipa) u cilju zaštite potrošača predstavlja činjenica da su njegova kontrolna ovlašćenja usmerena na organe uprave i javne službe, ako se radi o povredi propisa i opštih akata jedinica lokalne samouprave. ${ }^{80}$ To znači da je u ovom trenutku privatni sektor van njihove nadležnosti.

S druge strane, prednosti ovog rešenja su u mogućem korišćenju postojećeg administrativnog uređenja i kapaciteta u smislu da ovi organi već postoje i imaju određene resurse (prostorije za rad, materijal, opremu, stručnu službu), kao i da već postoji određena međusobna saradnja lokalnih ombudsmana u smislu prosleđivanja pritužbi, da postoji i Udruženje lokalnih ombudsmana Srbije, ${ }^{81}$ kao i da se u Srbiji aktuelno zagovara dalje jačanje i širenje mreže lokalnih ombudsmana. Pored navedenog, Zakon o Zaštitniku građana već predviđa mehanizme saradnje Zaštitnika građana sa ombudsmanom autonomne pokrajine, kao i sa lokalnim ombudsmanima u jedinicama lokalne samouprave u kojima je on ustanovljen. ${ }^{82} \mathrm{U}$ cilju specijalizacije i stvaranja kompetentnih

79 Analiza položaja lokalnih ombudsmana u Republici Srbiji, Komitet pravnika za ljudska prava - YUCOM, str. 32, (http://www.yucom.org.rs/wp-content/uploads/2020/01/Analizapolo\%C5\%BEaja-lokalnih-ombudsmana-u-Republici-Srbiji-1.pdf, 15. 9. 2020).

80 Prema članu 97. Zakona o lokalnoj samoupravi (Sl. glasnik RS, br. 129/07, 83/14 - dr. zakon, 101/16 - dr. zakon i 47/18) u jedinici lokalne samouprave može se ustanoviti lokalni ombudsman koji je ovlašćen da nezavisno i samostalno kontroliše poštovanje prava građana, utvrđuje povrede učinjene aktima, radnjama ili nečinjenjem organa uprave i javnih službi, ako se radi o povredi propisa i opštih akata jedinice lokalne samouprave. Dve ili više jedinica lokalne samouprave mogu doneti odluku o ustanovljavanju zajedničkog lokalnog ombudsmana. Nadležnost i ovlašćenja, način postupanja i izbora i prestanka dužnosti lokalnog ombudsmana uređuje se statutom i drugim opštim aktom.

81 https://www.ulos.org.rs/o-nama/.

82 Zaštitnik građana sarađuje sa ombudsmanom autonomne pokrajine i građanskim braniocem (ombudsmanom) u jedinicama lokalne samouprave u kojima je on ustanovljen, kao i sa nadležnim službama predsednika Republike i Skupštine, u cilju razmene informacija o uočenim problemima i pojavama u radu i postupanju organa uprave sa stanovišta zaštite i unapređenja ljudskih sloboda i prava. Ako Zaštitnik građana primi pritužbu koja se odnosi na povrede prava građana učinjene aktima, radnjama ili nečinjenjem organa uprave, a ne radi se o povredi republičkih zakona, drugih propisa i opštih akata, već o povredi propisa ili opšteg akta autonomne pokrajine, odnosno jedinice lokalne samouprave, dostaviće takvu pritužbu bez odlaganja ombudsmanu autonomne pokrajine, odnosno građanskom branio$\mathrm{cu}$ (ombudsmanu) jedinice lokalne samouprave, ako je ustanovljen. Ako organ autonomne 
timova zaposlenih, u okviru jednog sektora Zaštitnika građana mogla bi biti formirana odeljenja ili grupe koje bi bile zadužene za posebne probleme ili za pojedinačne sektore privrede (finansijske usluge, turizam i putovanja, telekomunikacione usluge i sl.).

Izneti predlog bi možda mogao biti prelazno rešenje, kako bi se u perspektivi stvorili uslovi za uvođenje specijalizovanog potrošačkog ombudsmana ili sistema sektorskih ombudsmana, koji bi sistemski pratili stanje u sektorima, identifikovali sistemske probleme i davali šire preporuke za promene, kao i smernice i druge instruktivne oblike uticaja na poslovne subjekte i njihove prakse kako bi se postiglo stvarno i efektivno ostvarivanje zakonskih prava potrošača. Posebno je pitanje položaja tog organa koji, iako se naziva ombudsman, može biti posmatran kao nezavisni državni organ, regulatorno telo, spoljni mehanizam kontrole rada uprave ili besplatni javni servis. Takođe je pitanje i da li bi on bio potpuno samostalan i nezavisan organ ili bi delovao u okviru neke od postojećih institucija, imajući u vidu prethodno navedena različita uporednopravna rešenja.

\section{ULOGA NARODNE BANKE SRBIJE}

Narodna banka Srbije kao poseban državni organ, samostalan i nezavisan u obavljanju funkcija, nadležna je i da izdaje i oduzima dozvole za rad poslovnim bankama i drugim finansijskim organizacijama, vrši kontrolu njihovog boniteta i zakonitosti poslovanja itd. ${ }^{83} \mathrm{U}$ svetlu teme ovog rada, njena kontrola je od posebnog značaja kada je reč o bankama i drugim finansijskim organizacijama, dobrovoljnim penzijskim fondovima i osiguravajućim društvima, jer svi ovi su-

pokrajine ili jedinice lokalne samouprave nadležan za pitanja zaštite prava građana primi pritužbu koja se odnosi na povrede republičkog zakona, drugog propisa ili opšteg akta, dostaviće takvu pritužbu, bez odlaganja Zaštitniku građana. Ako podnosilac u pritužbi ukazuje istovremeno na povredu republičkog zakona, drugog propisa ili opšteg akta i na povredu propisa ili opšteg akta autonomne pokrajine, odnosno jedinice lokalne samouprave, organ kome je pritužba dostavljena (Zaštitnik građana, ombudsman autonomne pokrajine ili građanski branilac-ombudsman jedinice lokalne samouprave) postupaće po njoj u delu svojih nadležnosti, a kopiju pritužbe će proslediti drugom nadležnom organu (Zaštitniku građana, ombudsmanu autonomne pokrajine ili građanskom braniocu-ombudsmanu jedinice lokalne samouprave, ako je takav organ ustanovljen), radi postupanja u delu njegovih nadležnosti, shodno st. 1. i 2. ovog člana. Videti član 34. stav 2. i član 35. Zakona o Zaštitniku građana (Sl. glasnik RS, br. 79/05 i 54/07).

83 Videti: Zakon o Narodnoj banci Srbije (Sl. glasnik RS, br. 72/03, 55/04, 85/05 - dr. zakon, 44/10, 76/12, 106/12, 14/15, 40/15 - odluka US i 44/18). Argumenti zbog kojih se kontrola od strane Narodne banke Srbije može podvesti u širem smislu pod određeni oblik upravne kontrole pre svega se odnose na činjenicu da Narodna banka ima upravna ovlašćenja i donosi upravne akte kojima preduzima određene mere, kao što su: upućivanje pismene opomene i nalogodavnog pisma, izricanje naloga za otklanjanje nepravilnosti uz izricanje novčane kazne, uvođenje prinudne uprave i oduzimanje dozvole za rad. Videti detaljnije: Milosavljević, B., 2017, Upravno pravo, Beograd, Pravni fakultet Univerziteta Union u Beogradu i JP Službeni glasnik, str. 190-191. 
bjekti, po pravilu, u svom poslovanju koriste razne tipske ugovore i opšte uslove poslovanja ${ }^{84}$ koji mogu sadržati i nepravične ugovorne odredbe.

Zakon o zaštiti korisnika finansijskih usluga ${ }^{85}$ ovlašćuje Narodnu banku Srbije da može utvrđivati da li je davalac finansijske usluge obavljao nepoštenu poslovnu praksu ili ugovarao nepravične odredbe. Narodna banka Srbije može utvrđivati ove okolnosti na osnovu sopstvenih saznanja, prigovora, pritužbi i obaveštenja korisnika ili drugih zainteresovanih lica, kao i drugih podataka kojima raspolaže. Ako utvrdi da je davalac finansijske usluge obavljao nepoštenu poslovnu praksu ili ugovarao nepravične odredbe, Narodna banka Srbije je ovlašćena i da to sankcioniše, tako što rešenjem može naložiti obustavu primene takve poslovne prakse, odnosno zabranu primene i ugovaranja tih odredaba, a može izreći i novčanu kaznu. ${ }^{86}$

Javnosti je dostupno nedovoljno podataka na osnovu kojih bi se mogao izvesti pouzdan zaključak o tome koliko su navedene mere koje može preduzimati Narodna banka efikasne kada su u pitanju nepoštene ugovorne odredbe. Prema podacima Narodne banke iz februara 2020. godine o preduzetim merama u oblasti zaštite korisnika finansijskih usluga, u 2019. godini doneto je jedno rešenje kojim su utvrđene nepravične ugovorne odredbe. ${ }^{87}$

84 Naš Zakon o zaštiti korisnika finansijskih usluga navodi četiri kriterijuma kojima bi davalac finansijske usluge trebalo da se rukovodi prilikom izrade sopstvenih opštih uslova poslovanja, te propisuje da je opštim uslovima poslovanja davalac finansijske usluge dužan da obezbedi primenu dobrih poslovnih običaja, dobru poslovnu praksu i fer odnos prema korisniku, kao i usklađenost ovih uslova s propisima. Opštim uslovima poslovanja davalaca finansijskih usluga se, u smislu ovog zakona, smatraju uslovi poslovanja koji se primenjuju na korisnike, uslovi za uspostavljanje odnosa između korisnika i davaoca finansijske usluge i postupak komunikacije između njih i uslovi za obavljanje poslovanja između korisnika i davaoca ove usluge. Ovaj zakon izričito određuje da opšti uslovi poslovanja obuhvataju i akte kojima se utvrđuju naknade i drugi troškovi koje davalac finansijskih usluga naplaćuje korisnicima (npr. tarifa naknade). Videti član 9. Zakona o zaštiti korisnika finansijskih usluga, Sl. glasnik RS, br. 36/11 i 139/14).

85 U odeljku 6. koji se odnosi na nepoštenu poslovnu praksu i nepravične ugovorne odredbe. Nepoštena poslovna praksa i nepravične ugovorne odredbe imaju značenje utvrđeno zakonom kojim se uređuje zaštita potrošača.

86 U iznosu od 200.000 do 2.000.000 dinara. Videti član 41. Zakona o zaštiti korisnika finansijskih usluga.

87 Tekst pod naslovom Preduzete mere u oblasti zaštite korisnika finansijskih usluga, objavljen 25. 2. 2020, (https://www.nbs.rs/internet/latinica/scripts/showContent.html?id=15249 \&konverzija=yes, 14. 9. 2020). Na istom mestu se navodi da je u 2019. godini po pritužbama doneto 20 rešenja, od čega je u 18 slučajeva izrečena i novčana kazna, s tim da se ukazuje na to da se rezultati rada u ovoj oblasti ne mogu detaljnije preneti javnosti zbog poverljivosti koja je ustanovljena zakonom, s tim da je od ukupno 1577 okončanih postupaka, broj osnovanih pritužbi iznosio 280 , i to kod društava za osiguranje 9,6\%, a kod banaka $26,6 \%$, što se objašnjava činjenicom da su bankarske usluge detaljnije regulisane. U postupku posredovanja, od ukupno 60 okončanih postupaka, u 19 postupaka je zaključen sporazum između osiguravajućeg društva i korisnika, dok su u slučaju banaka zaključena četiri sporazuma. Prosečna vrednost sporazuma je 337.812 dinara. Drugi javno dostupan podatak se odnosi na period od 1. 1. do 30. 6. 2018. godine u kome je Narodna banka donela 22 rešenja kojima je bankama naloženo otklanjanje nepravilnosti zbog povrede propisa kojima se uređuje oblast zaštite korisnika finansijskih usluga, $s$ tim da se dva rešenja odnose na nepoštenu poslovnu 


\section{ZNAČAJ POTROŠAČKOG OBRAZOVANJA I ULOGA UDRUŽENJA POTROŠAČA}

O kontroli pod uticajem javnog mnjenja moglo bi se u specifičnom smislu govoriti kada javnost, tj. društvo (u sociološkom smislu) pokazuje osetljivost na neprihvatljive odredbe koje vređaju opšti, tj. javni interes. Taj proces bi se, zajedno sa procesom autonomne kontrole koju vrše udruženja trgovaca, mogao zajedno označiti kao (privatna) samoregulacija ili nedržavna intervencija. Oba procesa u razvijenim i reagujućim društvima mogu biti veoma delotvorna, posebno kada postoji sinergija reagovanja i udruženja postrošača, sa jedne, i udruženja privrednika i trgovaca, s druge strane. Pretpostavka za ovakve vidove kontrole jeste obrazovano ili bar dovoljno informisano društvo, osetljivo na nepoštene i nekorektne pojave i voljno da dovoljno glasno reaguje na nefer situacije i prakse. ${ }^{88}$

Smatra se da osnov uspešne privrede i boljeg načina života čine, između osta$\log$, obrazovani potrošači, koji razumeju svoja prava i znaju kako da ih koriste. ${ }^{89}$ To se postiže kako podizanjem nivoa svesti kada je u pitanju zrelo, poslovno aktivno stanovništvo, tako i obrazovnim programima u školama za decu i mlade..$^{90}$ $\mathrm{O}$ značaju potrošačkog obrazovanja devedesetih godina $\mathrm{XX}$ veka govorilo se i u Ujedinjenim nacijama, što je 1999. godine posebno naglasio i tadašnji generalni sekretar Ujedinjenih nacija Kofi Anan, a i smernice i preporuke OECD-a stavljaju akcenat na finansijsku i potrošačku pismenost odraslog stanovništva. ${ }^{91}$ Reč je o kombinaciji formalnog i neformalnog obrazovanja koje treba da postigne da ljudi pažljivo čitaju kako bi razumeli odredbe, da traže dodatne informacije i pojašnjenja kada neke odredbe ne razumeju, tj. da ne potpisuju olako ugovore, kao i da znaju svoja prava. To se pored školskog obrazovanja, postiže i različitim sredstvima: javnim diskusijama, kampanjama, obukama, okruglim stolovima, potrošačkim sajmovima, posebnim internet sajtovima i platformama, postojanjem savetovališta za građane, novinskim tekstovima, televizijskim i radio emisijama i sl. Formalno i neformalno obrazovanje se danas smatra sastavnim delom kako sistema zaštite potrošača, tako i finansijskog obrazovanja. Projekte finansijske pismenosti potpomažu i podstiču Svetska banka, OECD i Evropska komisija.

praksu, a jedno na nepravične ugovorne odredbe. Izvor: list Politika, 21. 8. 2018. tekst pod naslovom: NBS kaznila 11 banaka, (http://www.politika.co.rs/sr/clanak/409741/NBS-kaznila11-banaka, 14. 9. 2020).

88 Vukadinović, S., 2019, str. 325.

89 Ivančević, K., Finansijsko obrazovanje potrošača i delatnost osiguranja, u: Jovanović, S., Slavnić, J., Marano, P. (ur.), 2016, Reforme i novi izazovi u pravu osiguranja, Palić, Udruženje za pravo osiguranja Srbije, str. 231.

90 O finansijskom obrazovanju mladih se u poslednje vreme dosta i govori i piše, pa je pored velikog broja članaka objavljeno i više priručnika, zbornika i monografija. Videti: Lucey, T., Cooter, K. (eds.), 2018, Financial Literacy for Children and Youth, New York, Peter Lang Publishing; Fabris, N., Luburić, R., 2017, Finansijsko obrazovanje dece i omladine, Beograd, HERAedu.

91 Detaljnije: Ivančević, K., 2010, Pravna zaštita potrošača korisnika usluge osiguranja i bankarske usluge (doktorska disertacija), Beograd, Pravni fakultet Univerziteta Union u Beogradu, str. 379-380. Ista autorka u nastavku (str. 383 i fn. 1515) ukazuje i na mnogobrojne studije i istraživanja koja su pokazala da potrošači slabo razumeju finansijske usluge i osnove ekonomije. 
Na nivou Evropske unije čine se posebni i značajni napori na polju kako finansijskog obrazovanja, tako i potrošačkog savetovanja kao i saradnje sa potrošačkim organizacijama, što sve ukupno ima i ulogu podizanja nivoa znanja. Takvi napori se čine od strane različitih aktera i institucionalizovani su kroz: Evropsku savetodavnu grupu za potrošače (ECCG), koja je glavni forum Komisije za konsultacije sa nacionalnim i evropskim potrošačkim organizacijama; Mrežu evropskih centara za potrošače (ECC-Net - The European Consumer Centres Network) koja potrošačima daje informacije i pruža im pomoć u vezi sa prekograničnim transakcijama i sporovima; mrežu FIN-NET koja pruža pomoć potrošačima prilikom rešavanja sporova sa pružaocima finansijskih usluga; mrežu za unutrašnje tržište SOLVIT, Evropsku pravosudnu mrežu za civilna i poslovna pitanja, a postojao je i poseban projekat namenjen obrazovanju potrošača Dolceta (Development of on line education tools for adults), na čijoj internet platformi su bili dostupni programi za učenje za sve članice EU na njihovim jezicima. ${ }^{92}$

Pored državnih organa, škola i medija, značajan činilac u informisanju i edukovanju građana imaju i udruženja potrošača. U našoj zemlji su veoma aktivne potrošačke organizacije. Ministarstvo trgovine, turizma i telekomunikacija, Sektor za zaštitu potrošača, ${ }^{93}$ vodi Evidenciju udruženja za zaštitu potrošača i saveza, a spisak se ažurira i javno je dostupan na zvaničnoj internet prezentaciji ovog ministarstva. ${ }^{94}$ Udruženja koja su evidentirana u Ministarstvu mogu da konkurišu za sredstva koja su obezbeđena u budžetu Republike Srbije i namenjena za pomoć u radu savetovališta koja pružaju informacije, savete i pravnu pomoć potrošačima (tzv. regionalna savetovališta ${ }^{95}$ ).

Naš Zakon o zaštiti potrošača kao jedno od osnovnih prava potrošača definiše pravo na edukaciju - sticanje osnovnih znanja i veština neophodnih za pravilan i pouzdan izbor proizvoda i usluga, kao i znanja o osnovnim pravima i dužnostima potrošača i načinu njihovog ostvarivanja. ${ }^{96}$ Pored toga, Zakon sadrži i posebne odredbe o edukaciji i informisanju potrošača koje sprovode udruženja za zaštitu potrošača i savezi udruženja, prema kojima udruženja i savezi udruženja pružaju i sprovode edukaciju i informisanje potrošača na nezavisan i objektivan način, koji ne sme da sadrži bilo kakav oblik oglašavanja. Nastavni program osnovnog i srednjeg obrazovanja treba da obuhvati i obrazovanje učenika osnovnih i srednjih škola o osnovnim principima zaštite potrošača, kao i o pravima i obavezama potrošača. Ministarstvo nadležno za zaštitu potrošača i evidentirana udruženja i savezi sarađuju sa osnovnim i srednjim školama u cilju edukacije učenika o potrošačkim pravima i obavezama. ${ }^{97}$

92 Detaljnije: Ivančević, K., 2014, Uvod u potrošačko pravo, Beograd, Pravni fakultet Univerziteta Union, str. 27.

93 https://mtt.gov.rs/sektori/sektor-za-zastitu-potrosaca/.

94 http://zastitapotrosaca.gov.rs/evidentirana-udruzenja.php?pismo=latinica.

95 Spisak regionalnih savetovališta je dostupan na: http://zastitapotrosaca.gov.rs/regionalna-savetovalista.php.

96 Videti član 2. stav 1. tačka 7. Zakona o zaštiti potrošača, Sl. glasnik $R S$, br. 62/14, 6/16 - dr. zakon i 44/18 - dr. zakon).

97 Član 16. Zakona o zaštiti potrošača, Sl. glasnik RS, br. 62/14, 6/16 - dr. zakon i 44/18 - dr. zakon. 
Strategija zaštite potrošača za period 2019-2024. godine ${ }^{98} \mathrm{u}$ okviru analize i ocene postojećeg stanja u delu koji se odnosi na ulogu udruženja potrošača konstatuje da udruženja potrošača imaju važnu ulogu u potrošačkoj politici, ali da je njihova regionalna raspodela neujednačena budući da je najveći udeo udruženja potrošača prisutan u Vojvodini, dok je relativno mali broj udruženja u Južnoj i Istočnoj Srbiji. Navodi se da je u registru Agencije za privredne registre Republike Srbije (APR) upisano 90 udruženja potrošača dok je 26 evidentirano u Evidenciji udruženja i saveza koju vodi Ministarstvo trgovine, turizma i telekomunikacija (MTTT).

\begin{tabular}{|l|c|c|c|}
\hline \multicolumn{1}{|c|}{ Region } & $\begin{array}{c}\text { Evidentirana udruženja } \\
\text { potrošača (MTTT) }\end{array}$ & $\begin{array}{c}\text { Udruženja } \\
\text { registrovana pri APR }\end{array}$ & $\begin{array}{c}\text { Broj obuhvaćenih } \\
\text { gradova }\end{array}$ \\
\hline Vojvodina & 9 & 35 & 18 \\
\hline Beograd & 6 & 13 & 1 \\
\hline $\begin{array}{l}\text { Šumadija i } \\
\text { Zapadna Srbija }\end{array}$ & 7 & 23 & 12 \\
\hline $\begin{array}{l}\text { Južna i Istočna } \\
\text { Srbija }\end{array}$ & 4 & 18 & \\
\hline
\end{tabular}

Tabela: Teritorijalna raspodela udruženja ${ }^{99}$

Strategija konstatuje da i pored velikog broja registrovanih udruženja potrošača pri APR-u, jedino se evidentirana udruženja potrošača pri MTTT-u mogu smatrati kao aktivna, budući da nadležna institucija njihov rad prati na godišnjem nivou i samim tim ga smatra kontinuiranim. Međutim, i pored toga što određena udruženja potrošača obezbeđuju sredstva iz drugih fondova (IPA fond, SIDA i drugo), evidentirana udruženja u dugoročnom periodu se u velikoj meri oslanjaju na finansijske podsticaje MTTT-a i u manjoj meri na podršku lokalne samouprave. Iz ovog razloga, ocenjuje se u Strategiji, njihova finansijska samoodrživost i dalje direktno zavisi od nadležne institucije i zahteva ozbiljan pristup kako bi u narednom periodu njihov rad dostigao nivo samoodrživosti. ${ }^{100}$

Za sagledavanje mogućeg domašaja i uloge udruženja potrošača ${ }^{101} \mathrm{u}$ zaštiti kolektivnih interesa potrošača, korisno je uočiti da je u Crnoj Gori ove godine

98 Sl. glasnik RS, br. 93/19.

99 Podaci su preuzeti iz Strategije zaštite potrošača za period 2019-2024. godine, Sl. glasnik RS, br. 93/19.

100 Strategija zaštite potrošača za period 2019-2024. godine, u kojoj se u nastavku naglašava da su odgovornost i transparentnost usluga koje udruženja potrošača pružaju ključne kako bi se stvorilo poverenje građana u ove institucije, a to zahteva jasan okvir za odabir ovih udruženja i unapređivanje sistema na osnovu koga se prate pokazatelji i performanse. Na istom mestu se ističe i da se kvalitet rešavanja prigovora uglavnom podstiče detaljnim priručnicima za rešavanje podnetih prigovora, lako dostupnih alata i primera za e-učenje izrade projekata koji podrazumevaju konkretne konsultacije i mogućnosti informisanja pre dostavljanja projektne ideje - međutim, takvi alati još uvek nisu maksimizirani od strane udruženja potrošača.

101 U našoj javnosti pažnju često privlače aktivnosti udruženja za zaštitu potrošača Efektiva. Videti: http://efektiva.rs/dobijanje-kredita/aktuelnosti-efektiva/potrosaci-aktuelnosti/. Stati- 
jedna potrošačka organizacija podnela prvu kolektivnu tužbu. Konkretno, u medijima je objavljena informacija da je marta 2020. godine Centar za zaštitu potrošača Crne Gore, kao nevladina, neprofitna i nepolitička organizacija, nakon pisanog upozorenja, pokrenuo prvu kolektivnu tužbu protiv jedne banke koja se odnosi na odredbe u vezi sa potrošačkim kreditima, za koju se ističe da je prva kolektivna tužba u Crnoj Gori, ali i u državama regiona i šire. ${ }^{102}$

$\mathrm{Na}$ faktičkom nivou, u našoj državi je od septembra 2018. godine omogućeno finansijsko obrazovanje i vaspitanje u osnovnim školama tako što su izrađeni priručnici o finansijskom obrazovanju u nastavi (priručnici za finansijsku pismenost), ${ }^{103}$ a u 34 osnovne škole je sproveden program obuke nastavnika. $\mathrm{Na}$ taj način je i u našoj zemlji počela realizacija projekata čiji je cilj da nastavnici unaprede svoja znanja iz domena finansijskog obrazovanja i vaspitanja i da se upoznaju sa didaktičko-metodološkim modelima za uključivanje finansijskog obrazovanja, kako bi ovo međupredmetno obrazovanje bilo uključeno u nastavu, a deci omogućeno da pomoću radnih svezaka, didaktičkih igara, radionica i edukativnih onlajn igrica uče na interaktivan i zabavan način, kao i da se pokretanjem prve obrazovno-digitalne interaktivne platforme za finansijsku pismenost u Srbiji ljudima svih uzrasta omogući da unaprede svoje finansijsko znanje i informišu se o važnim temama iz oblasti finansija, što uključuje i primenu opštih uslova poslovanja. ${ }^{104}$

Podizanje nivoa finansijske pismenosti građana i potrošačko obrazovanje direktno uključuju podizanje nivoa znanja o nepoštenim ugovornim odredbama i pravima u vezi sa njima. Što je viši nivo znanja i obrazovanja građana i što se više otvoreno govori u medijima o tome, npr. koje su klauzule ugovora nedopuštene, koja poslovna praksa je nepoštena, to je ovaj svojevrsni oblik kontrole oštriji, tj. veći je uticaj javnog mnjenja na kreatore tipskih ugovora da koriguju klauzule i načine kako da građane upoznaju sa pravnim posledicama njihove primene na ugovorni odnos koji zaključuju. Opisani uticaj obrazovanog društva i medija kao budnih čuvara zdravih društvenih vrednosti u reagujućim društvima predstavlja poseban vid kontrole od strane javnog mnjenja, koja se u odnosu na sudsku i

stika prigovora potrošača za period 2011-2018. godine pokazuje da je Nacionalna organizacija potrošača u navedenom periodu rešila 31.104 potrošačka prigovora, podnela više od 100 prekršajnih prijava i inicirala najmanje deset postupaka za zaštitu kolektivnih interesa potrošača. U strukturi navedenih prigovora, $2,28 \%$ se odnosi na raskid ugovora, $1,50 \%$ na pravo na odustajanje od ugovora, a 1,08\% na nepravične ugovorne odredbe, (http://www.potrosac. info/novosti/1272-statistika-prigovora-potrosaca).

102 https://www.bankar.me/2020/03/11/cezap-pokrenuo-kolektivnu-tuzbu-protiv-ckb/; https:// mina.news/mina-business/cezap-pokrenuo-prvu-kolektivnu-tuzbu-protiv-ckb/, pristup 15. 9. 2020.

103 http://www.mpn.gov.rs/predstavljeni-prirucnici-za-finansijsku-pismenost/.

104 Prvi ovakav pilot-projekat se u našoj zemlji sprovodi tokom školske 2018/19. godine. Priprema je počela oktobra 2017. godine i planirano je da ovaj projekat pod nazivom FinPis - Uključivanje finansijskog opismenjavanja u sistem obrazovanja i vaspitanja Republike Srbije obuhvati 1260 nastavnika i 15.000 dece iz 34 škole širom Srbije. Više informacija je dostupno na prethodno navedenoj veb-prezentaciji Ministarstva prosvete, nauke i tehnološkog razvoja, kao i na interaktivnoj veb-platformi ovog projekta (koja uključuje i onlajn igrice za decu), (http://finpis.mi.sanu.ac.rs). 
upravnu kontrolu (koje su direktne) može smatrati indirektnom (posrednom) kontrolom, ali i vrlo korisnom i delotvornom. ${ }^{105}$

Kada je u pitanju potrošačko obrazovanje, Strategija zaštite potrošača za period 2019-2024. godine ukazuje da je analizom dosadašnjih istraživanja i praćenjem tržišta uočeno da je potrebno targetirati određene demografske grupe kao posebno osetljive grupe potrošača (osobe starosti 7-19 godina i 65 godina i više, potrošače u ruralnim oblastima, osobe sa nižim nivoom obrazovanja i nižim zaradama), kao i da je podizanje svesti kontinuirani proces koji zahteva saradnju svih aktera kako bi se postigli efikasniji i delotvorniji rezultati. ${ }^{106}$

\section{ULOGA SUDA ČASTI}

Udruženja privrednika neretko imaju sopstvene mehanizme reagovanja na nepoštene ugovorne odredbe, naročito one sadržane u opštim uslovima. Privrednici koji posluju u Srbiji su u obavezi da primenjuju u svom poslovanju odredbe Kodeksa poslovne etike, ${ }^{107}$ a u slučaju da ih krše, može se pokrenuti postupak pred Sudom časti. ${ }^{108}$

Kodeks poslovne etike sadrži posebne odredbe koje se odnose na povredu poslovnog morala u vezi sa sastavljanjem ugovornih odredaba, te propisuje da je prilikom zaključenja ugovora privredni subjekt dužan da sačini ugovorne odredbe na način koji ne ostavlja sumnju u pogledu njihovog smisla i značenja. U slučaju kad je ugovor zaključen prema unapred odštampanom sadržaju, ili kada je ugovor na drugi način pripremljen i predložen od jedne ugovorne strane, nejasne odredbe tumačiće se u korist druge strane. ${ }^{109}$ Ovaj kodeks izričito propisuje da nisu u skladu sa poslovnom etikom elementi ugovora koji su nametnuti putem tipskih ugovora, korišćenjem teške ekonomske situacije, pretnje, prevare ili dovođenjem u zabludu, ako dovode do narušavanja ravnopravnog položaja ugovornih strana, kao i da će se suprotnim poslovnom moralu smatrati i sastojci ugovora koji nisu u srazmeri sa poslovnim rizikom koji se ugovorom preuzima. ${ }^{110}$

105 Vukadinović, S., 2019, str. 328-329.

106 Strategija zaštite potrošača za period 2019-2024. godine, Sl. glasnik RS, br. 93/19. U tom smislu, Strategijom su postavljeni opšti ciljevi komunikacionog plana: priprema i pokretanje medijske kampanje, uključujući specijalizovane TV i radio spotove koji će biti kreativni i privlačni za publiku; ažuriranje izgleda veb-sajta MTTT i obezbeđivanje njegove dostupnosti osobama s invaliditetom; otvaranje i vođenje naloga na društvenim mrežama radi boljeg povezivanja potrošača; priprema informativnih i promotivnih materijala s odgovarajućim sadržajem za svaku ciljnu grupu; razvoj savremenih vidova komunikacionih kanala koji na brz način nude informacije $\mathrm{u}$ oblasti zaštite potrošača; nadogradnja Nacionalnog registra potrošačkih prigovora u kojem se evidentiraju prigovori i uputi potrošača.

107 Sl. glasnik RS, br. 1/06.

108 O sudovima časti - njihovom pojmovnom određenju, organizaciji, nadležnosti, pravnoj prirodi, osobenosti postupka koji sprovode i prirodi odgovornosti koju utvrđuju, kao i o vrsti i prirodi mera koje izriču, detaljnije: Dabić, Lj., 2018, Sudovi časti pri privrednim komorama, Pravo i privreda, 4-6, str. 204-222.

109 Videti član 15. st. 1-2. Kodeksa poslovne etike, Sl. glasnik RS, br. 1/06.

110 Član 15. st. 3-4. Kodeksa poslovne etike, Sl. glasnik RS, br. 1/06. 
Zakon o privrednim komorama iz 2015. godine propisuje da se pri Privrednoj komori Srbije i privrednim komorama autonomnih pokrajina obrazuje sud časti. Odeljenja Suda časti Privredne komore Srbije mogu se obrazovati pri regionalnim privrednim komorama, odnosno privrednoj komori glavnog grada, a Sud časti se može obrazovati pri ugovornim privrednim komorama. Sud časti odlučuje u slučajevima povrede dobrih poslovnih običaja i poslovnog morala. Sud časti je nezavisan i samostalan u svom radu, a njegove odluke su konačne i izvršne $^{111}$ i imaju snagu pravosnažne sudske odluke. ${ }^{112}$

Sud časti je od značaja sa aspekta kontrole opštih uslova poslovanja, jer on može da utvrđuje odgovornost i da izriče određene mere kada primena određenih OUP ili odredaba koje oni sadrže predstavlja povredu dobrih poslovnih običaja i poslovnog morala, kao i povredu kojom se narušava jedinstvo tržišta, ${ }^{113}$ $s$ tim da treba reći da Sud časti ne odlučuje u potrošačkim sporovima. Konkretno, Sud časti utvrđuje odgovornost i izriče mere u postupku ${ }^{114}$ protiv članova Privredne komore Srbije i drugih privrednih subjekata, koji posluju na teritoriji Republike Srbije, a protiv kojih se podnosi zahtev zbog povreda dobrih poslovnih običaja i poslovnog morala. Sud časti je nadležan da utvrđuje i povrede dobrih poslovnih običaja i poslovnog morala koje učine strani privredni subjekti koji imaju registrovan ogranak, odnosno predstavništvo kod organa nadležnog za registraciju privrednih subjekata. ${ }^{115}$

Kao povreda dobrih poslovnih običaja mogu se, prema okolnostima slučaja, smatrati i postupci članova Komore kojima se nanosi šteta društvenoj zajednici, drugim privrednim subjektima i potrošačima, izigrava duh i smisao zakona i drugih propisa i ruši ugled zemlje u inostranstvu. ${ }^{116}$

Mere koje Sud časti može izreći zbog povrede dobrih poslovnih običaja i poslovnog morala su: (1) opomena; (2) javna opomena sa objavljivanjem na

111 Videti član 30. Zakona o privrednim komorama (Sl. glasnik RS, br. 11215), koji propisuje i da se organizacija, sastav, postupak, način rada Suda časti i mere koje izriče uređuju opštim aktom koje donosi Skupština Privredne komore Srbije. Slično je bilo predviđeno i članom 30. i članom 31. stav 1. Zakona o privrednim komorama (Sl. glasnik RS, br. 65/01, 36/09 i 99/11dr. zakon).

112 Snaga pravosnažne sudske odluke nije određena Zakonom o privrednim komorama, već Statutom Privredne komore. Videti član 65. stav 9. Statuta Privredne komore Srbije, Sl. glasnik RS, br. 39/16.

113 Član 65. stav 5. Statuta Privredne komore Srbije, Sl. glasnik RS, br. 39/2016.

114 O postupku pred Sudom časti videti čl. 24-69. Pravilnika o Sudu časti pri Privrednoj komori Srbije (Sl. glasnik RS, br. 114/17), koji, pored postupka, uređuje i organizaciju, sastav, način rada i mere koje izriče Sud časti.

115 Član 3. Pravilnika o Sudu časti pri Privrednoj komori Srbije, Sl. glasnik RS, br. 114/17.

116 Član 65. stav 6. Statuta Privredne komore Srbije (Sl. glasnik RS, br. 39/16), koji u narednom stavu 7. propisuje i da Sud časti odlučuje i zbog povreda Statuta, kodeksa i drugih akata organa Komore sa obaveznom snagom. Slično je i ranije bilo predviđeno čl. 99-100. Statuta Privredne komore Srbije (Sl. glasnik RS, br. 45/02, 107/03, 44/05, 29/09, 35/11, 46/11 i 103/11) i članom 9. Pravilnika o Sudu časti pri Privrednoj komori Srbije (Sl. glasnik RS, br. 39/06), s tim da je sada važećim (gorecitiranim) određenjem povrede poslovnih običaja proširen ovaj pojam, te on sada izričito obuhvata i postupke članova Komore kojima se nanosi šteta potrošačima, dok su ranije važeći propisi navodili samo štetu koja se nanosi društvenoj zajednici i drugim privrednim subjektima. 
Upravnom odboru Komore; (3) javna opomena sa objavljivanjem na internet stranici Komore. ${ }^{117}$

Sud časti koji je funkcionisao pri Privrednoj komori Beograda je bio veoma uspešan u radu. ${ }^{118}$ Danas Privredna komora Beograda ima, između ostalog, zadatak da se stara o negovanju dobrih poslovnih običaja i poslovnog morala i o poštovanju pravila dobrog poslovnog ponašanja privrednika koji posluju na području glavnog grada. ${ }^{119}$

Osim na nacionalnom ${ }^{120}$ ili regionalnom nivou svih sektora privrede u celini, autonomna kontrola bi mogla postojati i u pojedinim posebnim sektorima privrede u kojima deluju udruženja ${ }^{121}$ ili asocijacije trgovaca ili pružaoca usluga.

117 Izuzev gorenavedenih mera, Sud časti može izreći i druge mere koje su mu zakonskim propisima stavljene u nadležnost. Videti član 56. Pravilnika o Sudu časti pri Privrednoj komori Srbije (Sl. glasnik RS, br. 114/17). Pored navedenih mera, koje se u pravnoj teoriji uobičajeno nazivaju merama društvene discipline, Sud časti može izreći i zaštitne mere, utvrđene posebnim zakonom (videti član 57. Pravilnika o Sudu časti pri Privrednoj komori Srbije, Sl. glasnik RS, br. 114/17). Trenutno postoje dve vrste zaštitnih mere koje su predviđene u dva posebna zakona. Prva je brisanje reda vožnje, odnosno polaska prevozniku. Tačnije, prema članu 74. stav 2. Zakona o prevozu putnika u drumskom saobraćaju, u slučaju kada Sud časti Privredne komore Srbije utvrdi da je prevoznik povredio dobre poslovne običaje u prevozu, ministarstvo nadležno za poslove saobraćaja donosi rešenje o brisanju registrovanog reda vožnje, odnosno polaska iz reda vožnje iz registra (član 74. stav 2. Zakona o prevozu putnika u drumskom saobraćaju, Sl. glasnik RS, br. 68/15, 41/18, 44/18 - dr. zakon, 83/18). Druga je mera zabrana obavljanja delatnosti preduzetniku. Tačnije, prema članu 91. stav 6. tačka 5. Zakona o privrednim društvima, preduzetnik prestaje sa obavljanjem delatnosti ako mu je izvršnom odlukom suda časti komore u koju je učlanjen izrečena mera zabrane obavljanja delatnosti (član 91. stav 6. tačka 5. Zakona o privrednim društvima, Sl. glasnik RS, br. 36/11, 99/11, 83/14 - dr. zakon, 5/15, 44/18 i 95/18). Prethodno važeći Statut Privredne komore Srbije predviđao je pet zaštitnih mera i to: (1) zabranu učešća u radu organa i tela Komore; (2) zabranu učešća na sajmovima i izložbama; (3) zabranu poslovanja u spoljnoj trgovini u trajanju od tri do šest meseci; (4) zabranu samostalnog obavljanja delatnosti preduzetnika za određeno vreme; (5) brisanje reda vožnje, odnosno polazaka prevozniku, tj. preduzeću ili preduzetniku koji obavlja delatnost javnog prevoza (videti član 105. Statuta Privredne komore Srbije, Sl. glasnik RS, br. 45/02, 107/03, 44/05, 29/09, 35/11, 46/11 i 103/11).

118 Podaci dostupni u literaturi govore da je Sud časti pri Privrednoj komori Beograda primao značajan broj prijava. Tako je, na primer, u 2012. godini imao u radu 193 predmeta (uz ostvareni priliv u toku godine od 109 novih predmeta), od čega je rešen 101 predmet, a mere su izrečene u 42 predmeta. Videti detaljnije: Ivančević, K., 2014, Uvod u potrošačko pravo, Beograd, Pravni fakultet Univerziteta Union, str. 161-162 i fn. 611.

119 https://beograd.pks.rs/strana/pk-beograd-o-nama.

120 Pri Privrednoj komori Srbije, kao posebno telo za rešavanje sporova, obrazovana je Arbitraža Privredne komore Srbije. Kao ugledna arbitražna institucija u našoj zemlji, ova arbitraža odlučuje, miri i posreduje u privrednim sporovima između domaćih i/ili stranih privrednih subjekata, kada je ugovorena njena nadležnost. Arbitraža Privredne komore Srbije je nezavisna i samostalna u svom radu, a njena odluka je konačna i izvršna. Videti član 30. Zakona o privrednim komorama, Sl. glasnik RS, br. 112/15.

121 Jedno od najuticajnijih udruženja koje u ovom obliku postoji i deluje na našem tržištu, i to u sektoru turističih usluga, jeste YUTA - Nacionalna asocijacija turističkih agencija Srbije, koja je osnovana 1954. godine i posluje kao strukovna neprofitna organizacija. Članice YUTA su u ovom trenutku (15. 9. 2020) 262 turističke agencije koje imaju YUTA garanciju putovanja. YUTA ima i organizovano arbitražno rešavanje sporova pred Arbitražnim sudom YUTA, ali pred njim nisu dopuštene grupne žalbe putnika, već samo pojedinačne - putnika iz jednog ugovora o putovanju. Prema YUTA pravilima, dok traje, tj. dok se ne završi arbitražni postu- 
Sektorska autonomna kontrola kod nas u ovom trenutku još uvek nije razvijena, ali u posebnim zakonima postoje odredbe koje su od značaja za temu ovog rada. Tako, na primer, Zakon o turizmu sadrži posebne odredbe koje se odnose na opšte uslove putovanja, ${ }^{122}$ na njihovu sadržinu, ${ }^{123}$ kao i na obavezu da i tekst ugovora o organizovanju putovanja i opšti uslovi putovanja (kao i program putovanja i potvrda o putovanju) moraju da budu štampani slovnim znacima i brojevima koji su jednake veličine ali ne manjim od standardne veličine 12 , očigledno jasnog i čitljivog fonta. ${ }^{124}$ Pored toga, Nacionalna asocijacija turističkih agencija Srbije je objavila YUTA standarde za opšte uslove putovanja. ${ }^{125}$

Ukoliko nijedan od prethodno opisanih mehanizama ne da rezultate, uvek postoji mogućnost sudske zaštite, s tim da je ona u Srbiji aktuelno moguća samo u pojedinačnom slučaju, a ne i kroz kolektivnu tužbu, imajući u vidu da je 2013. godine Ustavni sud proglasio neustavnim članove Zakona o parničnom postupku kojima je bila uređena mogućnost podnošenja kolektivne tužbe. ${ }^{126}$

\section{ZAKLJUČAK}

Aktuelno stanje u Srbiji pokazuje da postoji potreba za daljim unapređenjem sistema zaštite potrošača, naročito u delu koji se odnosi na zaštitu kolektivnih interesa potrošača. Uporednopravna iskustva pokazuju da za to postoje i mogućnosti i primeri dobre prakse. U skladu sa tim, jedna od mogućnosti jeste da se prošire nadležnosti tela koje je nadležno za zaštitu konkurencije, što je u našem sistemu Komisija za zaštitu konkurencije, što bi značilo da se izmenama i dopunama Zakona o zaštiti konkurencije, ustanove, odnosno pridodaju nove nadležnosti ovoj nezavisnoj i samostalnoj organizaciji, a koje se odnose i na zaštitu potrošača. Mada se te nadležnosti pre odnose na nepoštene poslovne prakse (nego na nepoštene ugovorne odredbe). Nadalje, moguće je ponovno uvođenje sudske zaštite u vidu kolektivne tužbe, posebno imajući u vidu postignuti politički dogovor na nivou EU. Ipak, čini se da se tokom 2020. godine u našem društvu i medijima aktuelizuje ideja uvođenja potrošačkog ombudsmana. ${ }^{127}$

pak, stranke u sporu ne mogu istovremeno pokrenuti sudski ili neki drugi postupak, niti o predmetu spora obaveštavati medije. Detaljnije videti: http://www.yuta.rs.

122 Prema članu 70. Zakona o turizmu (Sl. glasnik RS, br. 17/19), organizator putovanja je dužan da opšte uslove putovanja utvrdi u skladu sa ovim zakonom, a na pitanja koja nisu posebno uređena ovim zakonom shodno primeni odgovarajuće odredbe zakona kojim se uređuje zaštita potrošača i zakona kojim se uređuju obligacioni odnosi. Ništave su odredbe ugovora o organizovanju putovanja kojima se isključuje ili smanjuje odgovornost organizatora putovanja.

123 Videti član 71. Zakona o turizmu.

124 Times New Roman, Arial, Calibri i sl. Videti član 74. Zakona o turizmu.

125 http://www.yuta.rs/yuta/o-nama/standardi-za-opste-uslove-putovanja-11.

$126 \mathrm{U}$ pojedinim zemljama, kao na primer u Poljskoj, individualnim zahtevom potrošača se može zaštititi i kolektivni interes potrošača jer u Poljskoj odluka suda kojom se neka ugovorna odredba proglašava nepravičnom deluje erga omnes. Ta odluka se objavljuje, a predmetna odredba se ne može više ugovarati u nekom drugom ugovoru. Detaljnije: Ivančević, K., 2014, Uvod u potrošačko pravo, Beograd, Pravni fakultet Univerziteta Union, str. 152.

127 O kome je u domaćoj nauci detaljno pisala profesorka Katarina Ivančević. Videti: Ivančević, K., 2013, Specijalizovani ombudsman za zaštitu potrošača, Pravo i privreda, 4-6, str. 342-356; 
Komparativna iskustva pokazuju da se skandinavski model potrošačkog ombudsmana pokazao veoma efikasnim. Iako bi takav model bio optimalan, imajući u vidu da je reč o specijalizovanom ombudsmanu čije bi uvođenje predstavljalo značajan poduhvat, kao i da i u drugim sektorima (npr. ravnopravnost polova) dolazi do pojave nezavisnih državnih organa čije su nadležnosti slične ili se delimično prepliću sa delokrugom zaštitnika građana, možda bi se kao jedno moguće rešenje mogla razmotriti transformacija postojećeg inokosnog zaštitnika građana u kolegijalni organ, koji bi obavljao i ulogu potrošačkog ombudsmana (poseban sektor sa odeljenjima), kao i proširenje nadležnosti i mreže lokalnih ombudsmana i jačanje njihove međusobne saradnje. Ovo iz razloga što je institucija Zaštitnika građana, odnosno opšteg ombudsmana u Srbiji već dala dobre rezultate i stvorila odgovarajući ugled u našem društvu. Iako bi u smislu ekonomičnosti kolegijalni ombudsman mogao biti prelazno rešenje, moguće je pretpostaviti i da bi poseban specijalizovani ombudsman bio efikasniji, te bi u daljoj budućnosti adekvatno rešenje bio sistem specijalizovanih ombudsmana.

Imajući u vidu postojeći vid upravnopravne zaštite kolektivnih interesa potrošača koji se ostvaruje u postupku pred Ministarstvom, razvoj ove oblasti bi se mogao kretati i u pravcu jačanja uloge potrošačkih organizacija i podizanja svesti građana - rad na obrazovanju, uz uvođenje vandsudskog i onlajn rešavanja potrošačkih sporova.

Sve navedeno pokazuje da je potrebno jačanje institucionalnih mehanizama za zaštitu kolektivnih interesa potrošača, kao i da su ovo samo neki od mogućih pravaca u neprekidnom traganju za adekvatnom zaštitom potrošača i nalaženjem najbolje kombinacije oblika njihove zaštite.

\section{LITERATURA}

1. Babić, I., 2011, Građansko pravo: uvod u građansko pravo, Beograd, Novi Sad, JP Službeni glasnik i Fakultet za evropske pravno-političke studije Univerziteta Singidunum.

2. Babović, B., 2014, Zaštita kolektivnih interesa potrošača, Anali Pravnog fakulteta u Beogradu, 2.

3. Blagojević, B., 1934, Ugovori po pristanku - formularni ugovori (doktorska rasprava), Beograd, Pravni fakultet Univerziteta u Beogradu.

4. Dabić, Lj., 2018, Sudovi časti pri privrednim komorama, Pravo i privreda, 4-6.

5. Đurđević, N., 1994, Kontrola opštih uslova poslovanja po osnovu pravičnosti, Pravni život, 11-12.

6. Fabris, N., Luburić, R., 2017, Finansijsko obrazovanje dece i omladine, Beograd, HERAedu.

7. Guidance on the interpretation and application of Council Directive 93/13/EEC on unfair terms in consumer contracts, 2019/C 323/04, Official Journal of the European Union 27. 9. 2019.

Ivančević, K., 2005, Ombudsman u osiguranju, Revija za pravo osiguranja: časopis za teoriju $i$ praksu osiguranja, 3-4, str. 34-37. 
8. Ivančević, K., 2005, Ombudsman u osiguranju, Revija za pravo osiguranja: časopis za teoriju i praksu osiguranja, 3-4.

9. Ivančević, K., 2010, Pravna zaštita potrošača korisnika usluge osiguranja i bankarske usluge (doktorska disertacija), Beograd, Pravni fakultet Univerziteta Union u Beogradu.

10. Ivančević, K., 2013, Specijalizovani ombudsman za zaštitu potrošača, Pravo i privreda, 4-6.

11. Ivančević, K., 2014, Uvod u potrošačko pravo, Beograd, Pravni fakultet Univerziteta Union u Beogradu.

12. Ivančević, K., Finansijsko obrazovanje potrošača i delatnost osiguranja, u: Jovanović, S., Slavnić, J., Marano, P. (ur.), 2016, Reforme i novi izazovi u pravu osiguranja, Palić, Udruženje za pravo osiguranja Srbije.

13. Jankovec, I., 1997, Sudska kontrola opštih uslova poslovanja, u: Borislav T. Blagojević, Niš, Pravni fakultet Univerziteta u Nišu - Institut za pravna i društvena istraživanja.

14. Jovanić, T., Uloga uprave u zaštiti kolektivnih interesa potrošača, u: Bourgoignie, T., Jovanić, T. (eds.), 2013, Strengthening Consumer Protection in Serbia - Liber Amicorum Svetislav Taboroši, Beograd, Pravni fakultet Univerziteta u Beogradu.

15. Jovičić, K., Dabetić-Trogrlić, V., 2016, Komentar Zakona o zaštiti potrošača, Beograd, Glosarijum.

16. Karanikić Mirić, M., 2014, Kolektivna zaštita potrošača u srpskom pravu, Anali Pravnog fakulteta Univerziteta u Zenici, 14.

17. Karanikić Mirić, M., Čađenović, Z., 2010, Transponovanje pojedinih direktiva: Direktiva o nepravičnim ugovornim odredbama (93/13), u: Civil Law Forum for South East Europe: Collection of studies and analyses - First Regional Conference, Deutsche Gesellschaft für Technische Zusammenarbeit: Offener Regionalfonds für Südosteuropa - Rechtsreform, Cavtat, Vol. III.

18. Lucey, T., Cooter, K., (eds.), 2018, Financial Literacy for Children and Youth, New York, Peter Lang Publishing.

19. Milosavljević, B., 2017, Upravno pravo, Beograd, Pravni fakultet Univerziteta Union u Beogradu i JP Službeni glasnik.

20. Nagy, Z., Somsák, S., 2019, The Micro- and Macro Level Instruments of financial consumer protection in Hungarian law, Zbornik radova Pravnog fakulteta u Novom Sadu, 4.

21. Protić, D., 2020, Zaštita potrošača u Srbiji: koji su mogući pravci napretka?, Beograd, Centar za evropske politike.

22. Vodinelić, V., 2016, Javno i privatno pravo, Beograd, Službeni glasnik.

23. Vukadinović, S., 2019, Opšti uslovi poslovanja u obligacionom i međunarodnom trgovinskom pravu: pojam, zaključenje, tipične klauzule i kontrola (doktorska disertacija), Beograd, Pravni fakultet Univerziteta Union u Beogradu.

\section{PROPISI}

1. Kodeks poslovne etike, Sl. glasnik RS, br. $1 / 06$.

2. Pravilnik o Sudu časti pri Privrednoj komori Srbije, Sl. glasnik RS, br. 114/17.

3. Pravilnik o Sudu časti pri Privrednoj komori Srbije, Sl. glasnik RS, br. 39/06.

4. Statut Privredne komore Srbije, Sl. glasnik RS, br. 39/16. 
5. Statut Privredne komore Srbije, Sl. glasnik RS, br. 45/02, 107/03, 44/05, 29/09, 35/11, 46/11 i 103/11.

6. Strategija zaštite potrošača za period 2019-2024. godine, Sl. glasnik RS, br. 93/19.

7. Zakon o lokalnoj samoupravi, Sl. glasnik RS, br. 129/07, 83/14 - dr. zakon, 101/16 dr. zakon i 47/18.

8. Zakon o Narodnoj banci Srbije, Sl. glasnik RS, br. 72/03, 55/04, 85/05 - dr. zakon, $44 / 10,76 / 12,106 / 12,14 / 15,40 / 15$ - odluka US i 44/18.

9. Zakon o prevozu putnika u drumskom saobraćaju, Sl. glasnik RS, br. 68/15, 41/18, $44 / 18$ - dr. zakon, 83/18.

10. Zakon o privrednim društvima, Sl. glasnik RS, br. 36/11, 99/11, 83/14 - dr. zakon, 5/15, 44/18 i 95/18.

11. Zakon o privrednim komorama, Sl. glasnik RS, br. 65/01, 36/09 i 99/11 - dr. zakon.

12. Zakon o privrednim komorama, Sl. glasnik RS, br. 112/15.

13. Zakon o trgovini, Sl. list SRJ, br. 32/93.

14. Zakon o turizmu, Sl. glasnik RS, br. 17/19.

15. Zakon o varstvu potrošnikov, Uradni list $R S$, št. 98/04 - uradno prečiščeno besedilo, 114/06 - ZUE, 126/07, 86/09, 78/11, 38/14, 19/15, 55/17 - ZKolT in 31/18.

16. Zakon o zaštiti potrošača, Sl. glasnik RS, br. 62/14, 6/16 - dr. zakon i 44/18 - dr. zakon.

17. Zakon o zaštiti korisnika finansijskih usluga, Sl. glasnik RS, br. 36/11 i 139/14.

18. Zakon o zaštitniku građana, Sl. glasnik RS, br. 79/05 i 54/07.

19. Zakon o zaštiti potrošača u Bosni i Hercegovini, Sl. glasnik BiH, br. 25/06 i 88/15.

\section{OSTALI IZVORI}

1. Rešenje Ministarstva trgovine, turizma i telekomunikacija broj: 330-00-00028/201811 od 12. juna 2018. godine.

2. Rešenje Ministarstva trgovine, turizma i telekomunikacija broj: 330-00-00091/201611 od 4. juna 2018. godine.

3. Rešenje Ministarstva trgovine, turizma i telekomunikacija broj: 330-00-00019/201511 od 14. maja 2018. godine.

\section{IZVORI SA INTERNETA}

https://www.accc.gov.au

https://www.afca.org.au

http://www.airlinecustomeradvocate.com.au

https://www.bankar.me/2020/03/11/cezap-pokrenuo-kolektivnu-tuzbu-protiv-ckb/

https://beograd.pks.rs/strana/pk-beograd-o-nama

https://cep.org.rs/blogs/zastitnik-potrosaca-karika-koja-nedostaje/

http://www.clauses-abusives.fr

https://www.danas.rs/ekonomija/cep-zastitnik-potrosaca-stit-od-svemocnih-trgovaca/ https://www.dijalog.net/cep-zastitnik-potrosaca-karika-koja-nedostaje/

http://efektiva.rs/dobijanje-kredita/aktuelnosti-efektiva/potrosaci-aktuelnosti/ 
https://euractiv.rs/2-srbija-i-eu/158-saoptenja/14714-potroai-u-srbiji-nemaju-oslonacza-zatitu-svojih-prava

https:/eur-lex.europa.eu/legal-content/EN/TXT/?uri=CELEX:52018PC0184

https://www.europarl.europa.eu/news/en/press-room/20200619IPR81613/new-rulesallow-eu-consumers-to-defend-their-rights-collectively

http://finpis.mi.sanu.ac.rs

https://www.instore.rs/svet/eu-postigla-dogovor-o-kolektivnoj-zastiti-potrosaca-12070. html

https://mina.news/mina-business/cezap-pokrenuo-prvu-kolektivnu-tuzbu-protiv-ckb/

http://www.mpn.gov.rs/predstavljeni-prirucnici-za-finansijsku-pismenost/

http://mtt.gov.rs/informacije/zastita-potrosaca/resenje-o-povredi-kolektivnog-interesapotrosaca/

https://mtt.gov.rs/sektori/sektor-za-zastitu-potrosaca/

https://www.nbs.rs

https://www.ombudsman.rs/

http://www.politika.co.rs/sr/clanak/409741/NBS-kaznila-11-banaka

http://www.politika.rs/scc/clanak/457269/Treba-li-Srbiji-potrosacki-ombudsman

http://www.potrosac.info/novosti/1272-statistika-prigovora-potrosaca

https://www.tio.com.au

https://www.ulos.org.rs/o-nama/

http://www.yuta.rs/yuta/o-nama/standardi-za-opste-uslove-putovanja-11

http://zastitapotrosaca.gov.rs 


\title{
MECHANISMS OF COLLECTIVE CONSUMER PROTECTION AGAINST UNFAIR CONTRACT TERMS
}

\author{
Slobodan Vukadinović
}

SUMMARY

The author first analyzes the current situation in Serbia in terms of protecting the collective interests of consumers. The subject of the analysis is the role and manner of action of various bodies for protection of collective interests of consumers, especially against unfair contract terms. It is further examined the real scope of existing mechanisms, their effectiveness and results and, especially: administrative control, i.e. the procedure conducted by the competent ministry, the powers of the National Bank of Serbia, the role of the Court of honour and the measures it can impose, the role of consumer associations and the importance of consumer education. The author researches comparative legal solutions, paying special attention to the consumer ombudsman and other specialized ombudsmen. The author analyzes the system of sectoral industrial ombudsmen and commissioners in Australia, and given their concrete results for the efficiency of these bodies, it shows their effectiveness in consumer protection. Several published system reports and system powers of these bodies which allow them to identify problems related to processes and practices that can cause harm to consumers and small businesses, work with service providers to implement needed changes, and initiate improvements that lead to better results for consumers and the industry are pointed out. Based on the examples of good practice in other countries and comparative experiences, proposals for improvement of the existing combination of mechanisms for the protection of collective consumer interests in Serbia and consumer protection in general are provided. As the paper analyzes the current debate in Serbian society about the possibility of introducing a consumer ombudsman, the author considers a possible transitional solution while preserving the basic idea of authority and competence of an independent state body. The proposal is reflected in the possibility of expanding the competences of the existing ombudsman and its cooperation with the network of local ombudsmen, having in mind that citizens approach these institutions regarding consumer protection problems, as well as based on certain experiences from comparative law. Ideally, the author emphasizes the positive effects of the system of specialized sectoral ombudsmen, which have proven their effectiveness in comparative law, and which could be applied in the domestic system. The potential greater role of the National Assembly is also pointed out, i.e. to use the existing institutional forms of parliamentary control that could contribute to the improvement of consumer protection.

Key words: consumers, collective protection, collective interest, unfair contract terms, ombudsman, court of honour, National Bank, administrative control. 